\title{
Methane in the Baltic and North Seas and a reassessment of the marine emissions of methane
}

\author{
H. W. Bange, U. H. Bartell, S. Rapsomanikis, and M. O. Andreae \\ Biogeochemistry Department, Max Planck Institute for Chemistry, Mainz, Germany
}

\begin{abstract}
During three measurement campaigns on the Baltic and North Seas, atmospheric and dissolved methane was determined with an automated gas chromatographic system. Areaweighted mean saturation values in the sea surface waters were $113 \pm 5 \%$ and $395 \pm 82 \%$ (Baltic Sea, February and July 1992) and $126 \pm 8 \%$ (south central North Sea, September 1992). On the bases of our data and a compilation of literature data the global oceanic emissions of methane were reassessed by introducing a concept of regional gas transfer coefficients. Our estimates computed with two different air-sea exchange models lie in the range of 11-18 $\mathrm{Tg} \mathrm{CH}_{4} \mathrm{yr}^{-1}$. Despite the fact that shelf areas and estuaries only represent a small part of the world's ocean they contribute about $75 \%$ to the global oceanic emissions. We applied a simple, coupled, threelayer model to evaluate the time dependent variation of the oceanic flux to the atmosphere. The model calculations indicate that even with increasing tropospheric methane concentration, the ocean will remain a source of atmospheric methane.
\end{abstract}

\section{Introduction}

Methane is an atmospheric trace gas that contributes about $15 \%$ to the greenhouse effect [Houghton et al., 1990] and plays an important role in tropospheric and stratospheric chemistry [Cicerone and Oremland, 1988]. Today, the global tropospheric concentration of methane is increasing at an annual rate of about 0.7-1\% [Steele et al., 1987, 1992; Khalil and Rasmussen, 1990]. On the basis of estimates of the sources and sinks of methane, predictions of further impacts on the world's climate can be made. Therefore it is necessary to evaluate the contributions of natural and anthropogenic sources to the global budget of methane. The world's oceans, as a natural source of methane, play only a modest role in the global methane budget. Oceanic emissions account for about $2 \%$ of all natural and anthropogenic sources [Cicerone and Oremland, 1988]. However, an accurate assessment of the oceanic source is still missing because of the paucity of available data [Ehhalt, 1974; Ehhalt and Schmidt, 1978; Cicerone and Oremland, 1988; Lambert and Schmidt, 1993].

In this paper we present recent measurements of atmospheric and dissolved methane from different marine environments. Data sets from two cruises on the Baltic Sea and one campaign on the North Sea, together with data from the literature, are the basis for a reassessment of the release of methane from the ocean to the atmosphere. Using a simple three-layer model, we evaluate the time dependent variation of the flux across the ocean-atmosphere interface due to increasing tropospheric methane concentrations.

Copyright 1994 by the American Geophysical Union.

\section{Study Areas and Cruise Tracks}

\section{Baltic Sea}

On basis of the hydrographic and bathymetric conditions the Baltic Sea can be divided into a series of basins (e.g., Belt Sea, Bornholm Sea, Gotland Sea, and Bothnian Sea) [Ehlin, 1981; Omstedt, 1990]. These basins (except the shallow transition basins Kattegat, Belt Sea, and Arkona Sea) are characterized by a permanent salinity stratification [Kullenberg, 1981]. The freshwater supply from the rivers and the discontinuously inflowing saline North Sea water result in a brackish surface layer and more saline deep and bottom water masses. The two Baltic cruises took place in February 1992 and July/August 1992 on the German research vessel $\mathrm{R} / \mathrm{V}$ Alexander von Humboldt. On the first cruise we occupied 63 stations in the southern Belt Sea, Arkona Sea, Bornholm Sea, and Gotland Sea. The second cruise covered 23 selected stations with the same coordinates as those occupied during the first cruise (Figure 1a).

\section{North Sea}

The North Sea forms part of the European shelf and can be classified as a coastal sea. In contrast to the Baltic, the North Sea is characterized by the great influence of tidal motions on the ecological conditions. Owing to the tides, pronounced horizontal and vertical exchange and transport effects occur. The salinity distribution is dominated by water masses entering from the North Atlantic and the British Channel [Otto et al., 1990]. Our measurements were made during a campaign on the research platform R/P Nordsee (September 1992) located in the southern part of the central North Sea $\left(54^{\circ} 42^{\prime} N, 7^{\circ} 10^{\prime} \mathrm{E}\right)$ (Figure 1b).

\section{Methods}

For the determination of atmospheric and dissolved methane we used a gas chromatographic (GC) system which was operated 


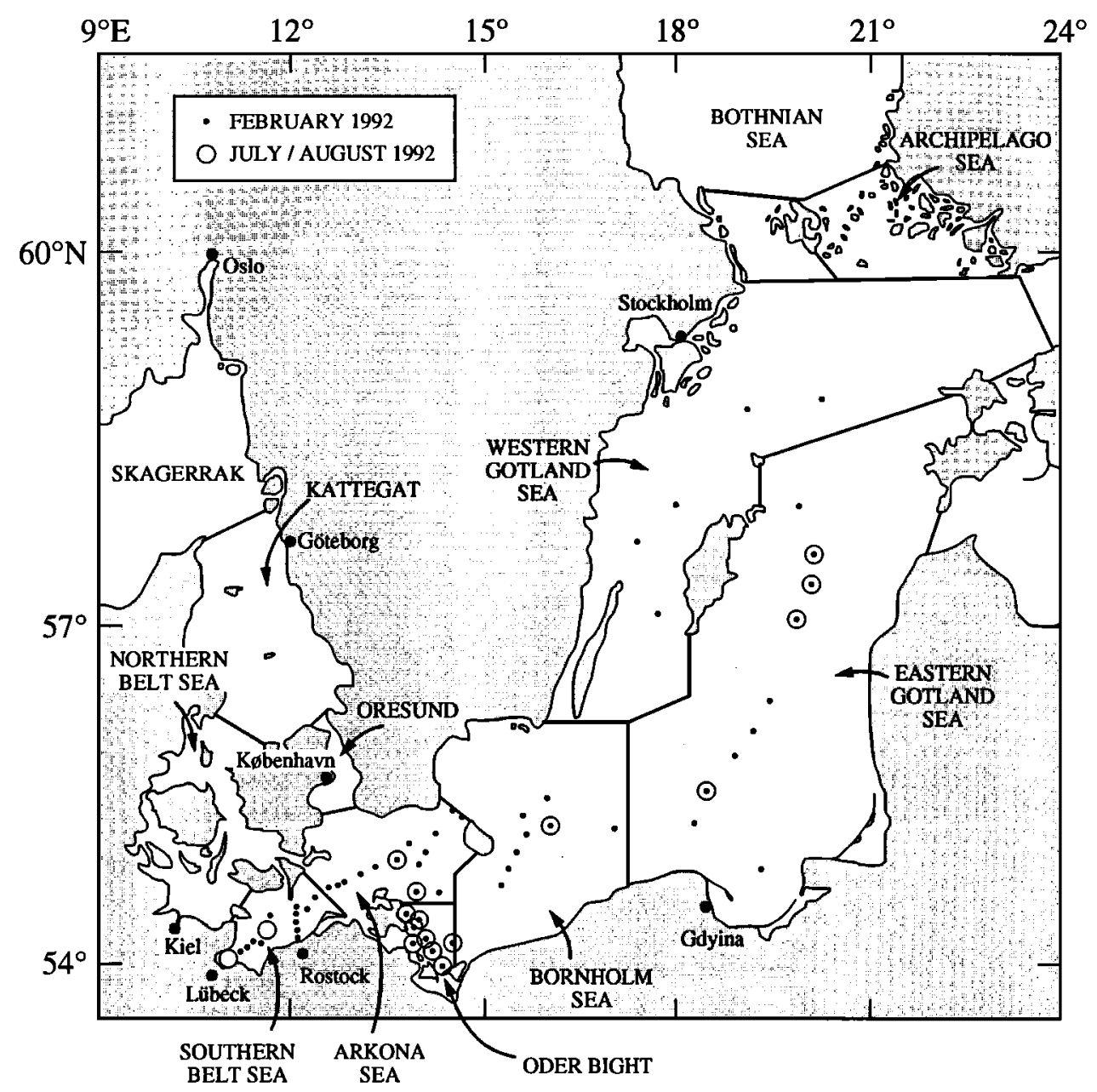

Figure 1a. Cruise tracks (not all stations indicated) of the two cruises on the Baltic Sea.

semiautomatically during the first cruise and fully automatically during the following cruises. Air was pumped continuously (1$\left.2 \mathrm{~L} \mathrm{~min}^{-1}\right)$ through $9.6 \mathrm{~mm}$ (OD) $(6.4 \mathrm{~mm}$ (ID)) polypropylene tubing from the ship's mast into the lab. The maximum length of the tubing was $90 \mathrm{~m}$ (R/P Nordsee), resulting in a maximal flushing time of about $3 \mathrm{~min}$. The location of the air inlet was chosen to avoid contamination from the exhaust of the ship's engine. Seawater was pumped continuously $\left(15 \mathrm{~L} \mathrm{~min}^{-1}\right.$ Baltic Sea, $30 \mathrm{~L} \mathrm{~min} \mathrm{~min}^{-1}$ North Sea) from a depth of 3-5 m into the lab using the ship's water pumps. By means of a seawater-air equilibrator developed by R.F. Weiss (Scripps Institution of Oceanography, La Jolla, California) the surface seawater was equilibrated with sample air (for details, see Butler et al. [1988]). Temperature differences between the seawater and the water in the equilibrator due to heating from the pumps were observed during the three expeditions. The differences ranged from $2 \pm 0.1^{\circ} \mathrm{C}$ (winter cruise, Baltic Sea) to $0.8 \pm 0.1^{\circ} \mathrm{C}$ (summer cruise, Baltic Sea) and $0.5 \pm 0.1^{\circ} \mathrm{C}$ (North Sea). Therefore calculated saturation values were corrected for this temperature difference. Possibly occurring methane production within the equilibrator was only observed during the second Baltic Sea cruise and was eliminated by cleaning when necessary.

The setup of our system consisted of four sample gas streams (ambient air, equilibrator headspace, and two standards) which could be selected for analysis with a system of three magnetic valves. Before the analysis the sample gas streams were dried with Sicapent ${ }^{\mathrm{TM}}$ (phosphorus pentoxide drying agent with indicator, E. Merck, Darmstadt, Germany). After the sample stream passed the moisture trap a 2-mL thermostated sample loop was flushed for $5 \mathrm{~min}$ with a sample flow of $25 \mathrm{~mL} \mathrm{~min} \mathrm{~min}^{-1}$ and then the sample was injected. We used helium $\left(55 \mathrm{~mL} \mathrm{~min}^{-1}\right)$ as carrier gas and hydrogen $\left(30 \mathrm{~mL} \mathrm{~min}^{-1}\right)$ and synthetic air $\left(250 \mathrm{~mL} \mathrm{~min}^{-1}\right)$ as flame gases. For the gas chromatographic separation we used a packed column $(1.80 \mathrm{~m} \times 3.2 \mathrm{~mm}$, stainless steel) filled with washed molecular sieve 5A (mesh 80/100, Alltech Associates, Inc.). The GC oven was operated isothermally $\left(60^{\circ} \mathrm{C}\right)$, and the heated zone of the flame ionization detector was held at a temperature of $250^{\circ} \mathrm{C}$. Two sets of standard gas mixtures were used for calibration. On the first cruise we used a mixture of methane in synthetic air with methane mixing ratios of 1.80 and 5.96 parts per million by volume (ppmv) $\pm 5 \%$. The second set had methane mixing ratios of 1.73 and 3.02 ppmv $\pm 2 \%$ in synthetic air and was calibrated by the manufacturer (DEUSTE Steininger GmbH, Mühlhausen, Germany) against standards of the U.S. National Institute of Standards and Technology (Gaithersburg, Maryland). The average absolute error of a single measurement was $\pm 0.1 \mathrm{ppmv}$.

During the Baltic Sea cruises the measurements of atmospheric and dissolved methane were performed when the ship was on station (time resolution $10 \mathrm{~min}$ on the first cruise and 


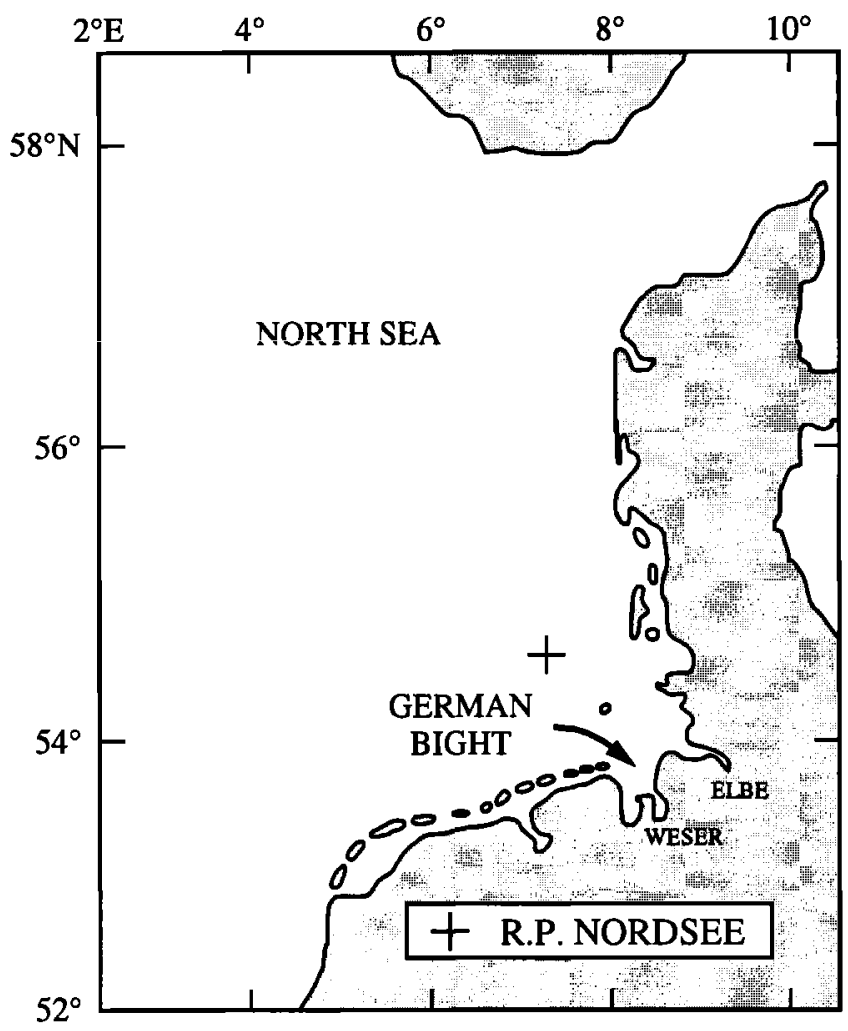

Figure 1b. Location of the research platform R/P Nordsee in the south central North Sea.

25 min on the second). The number of measurements during a single station varied, depending on the time spent at the position. Measurements of the standard gas mixtures were performed during the time when the ship moved to the next station. A continuous working mode was applied on the R/P Nordsee. During this campaign a series of measurements of atmospheric and dissolved methane followed by standards was repeated every $125 \mathrm{~min}$.

Saturation values were calculated as the ratio of dissolved methane to the expected equilibrium value derived from the ambient air concentration by applying the equation of Wiesenburg and Guinasso [1979]. Fluxes of methane across the seawater-atmosphere interface were computed with the equations of Liss and Merlivat [1986]. The transfer coefficient was corrected according to the Schmidt number Sc of methane ( $S c=$ kinematic viscosity of seawater/diffusion coefficient of methane) at the actual salinity and temperature of the seawater. Diffusion coefficients were obtained from the expression of Jähne et al. [1987], and the kinematic viscosity was calculated with the equations given by Siedler and Peters [1986]. All meteorological and oceanographic data were obtained from the ships' records and conductivity-temperature-depth (CTD) measurements performed during the cruises. The wind speed, recorded at different heights during the three expeditions, was normalized to a $10-\mathrm{m}$ height by using a neutral drag coefficient [Garratt, 1977].

\section{Results}

During both Baltic Sea cruises the surface waters were found to be supersaturated with respect to the ambient atmospheric concentrations of methane (Figures $2 a$ and $2 b$ ). The atmospheric mixing ratios during both cruises were almost uniform and ranged from 1.58 to $2.68 \mathrm{ppmv}$ (average $1.89 \pm 0.16 \mathrm{ppmv}$, winter cruise) and 1.72 to $2.22 \mathrm{ppmv}$ (average $1.89 \pm 0.09$, summer cruise). An overview of the average saturations measured on the two cruises is given in Figure 3. The comparison of the two data sets shows a strong seasonal variation. During winter conditions (February 1992) the areaweighted average saturation was $113 \pm 5 \%$, which is much lower than the area-weighted average saturation of $395 \pm 82 \%$ found under summer conditions (July/August 1992) (Table 1). A more detailed description of the distribution of the methane saturation is obtained by looking at the saturations observed in the different basins of the Baltic Sea (Table 2). The mean saturation values were generally higher in summer compared with winter, but the differences were not uniform. In the southern Belt Sea we found the strongest differences, whereas the saturation values of the eastern Gotland Sea show only a modest variation. A slight trend of decreasing saturation values from the southern Belt Sea $(162 \pm 41 \%)$ to the western Gotland Sea $(104 \pm 2 \%)$ was observed in winter. This trend was more pronounced during the summer cruise. During the summer expedition the saturation values ranged from $3760 \pm 3520 \%$ (southern Belt Sea) to $160 \pm 24 \%$ (eastern Gotland Sea). The data from the southern Belt Sea generally show great variability compared with data from the other basins. However, measurements at stations in the southern Belt Sea or Arkona Sea, which are expected to have coastal influences, showed significantly higher values during both cruises. The Oder Bight, a part of the southern Arkona Sea and influenced by the plume of the river Oder, is a good example of a coastal area. We observed in this region a clear relationship between salinity and methane water concentrations (Figures $4 \mathrm{a}$ and $4 \mathrm{~b}$ ). During both the winter and the summer cruise the concentrations of dissolved methane in the Oder Bight decreased with increasing salinity.

For each station we calculated flux densities based on the actual saturation value and the actual wind speed normalized to $10 \mathrm{~m}$ height. These flux densities computed with the equations of Liss and Merlivat [1986] ranged during the winter cruise from $0.11 \pm 0.2810^{-3} \mathrm{nmol} \mathrm{m}^{-2} \mathrm{~s}^{-1}$ to $0.17 \pm 0.03 \mathrm{nmol} \mathrm{m}^{-2} \mathrm{~s}^{-1}$. For the summer expedition we calculated flux densities of $1.17 \pm$ $0.2310^{-3} \mathrm{nmol} \mathrm{m}^{-2} \mathrm{~s}^{-1}$ to $13.9 \pm 2.3 \mathrm{nmol} \mathrm{m}^{-2} \mathrm{~s}^{-1}$ (Table 1).

In September 1992 we measured atmospheric and dissolved methane in the southern central North Sea at one station during 14 days, which provided a time series (Figure 5a). The atmospheric mixing ratio ranged from 1.70 to $2.46 \mathrm{ppmv}$, with an average value of $1.92 \pm 0.10 \mathrm{ppmv}$. Except for three single measurements, the surface water was supersaturated with methane during the campaign. During the first 3 days the saturation shows a slight decreasing trend from $140 \%$ to $115 \%$, then for the next 5 days the values increase up to $140 \%$. During the following 5 days the saturation values slightly decrease again to saturation values of about $115 \%$ (Figure $5 \mathrm{~b}$ ). Since the saturation values showed no significant trend, we averaged them over the measurement period, $126 \pm 8 \%$. The calculated flux densities were in the range of $-6.6 \pm 8.010^{-3} \mathrm{nmol} \mathrm{m}^{-2} \mathrm{~s}^{-1}$ to $0.12 \pm 0.03 \mathrm{nmol} \mathrm{m}^{-2} \mathrm{~s}^{-1}$. The average flux density was $0.025 \pm$ $0.023 \mathrm{nmol} \mathrm{m}^{-2} \mathrm{~s}^{-1}$ (Table 1).

\section{Discussion}

Methanogenesis (anoxic microbial fermentation of organic matter) is the sole known pathway for the formation of biogenic 


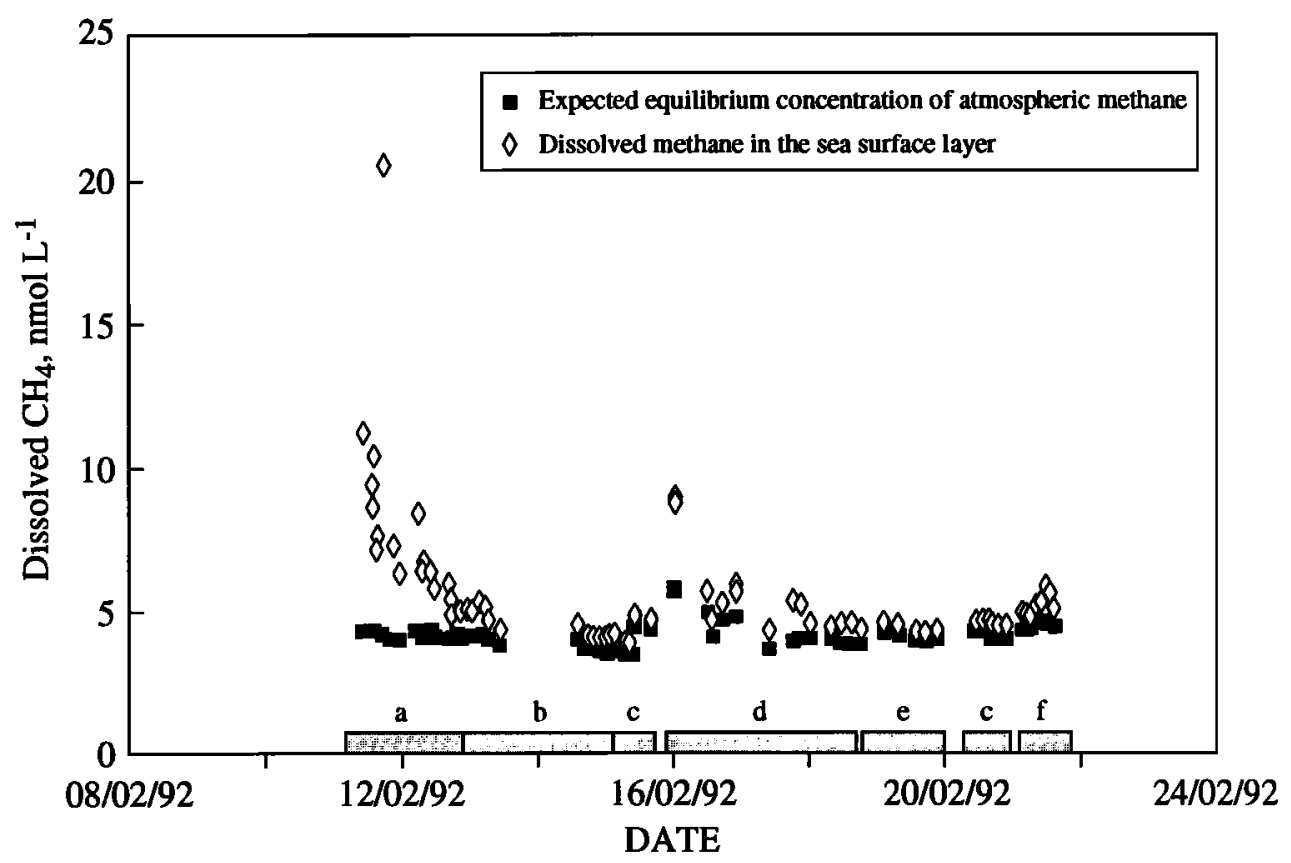

Figure 2a. Dissolved and equilibrium methane concentrations during the winter cruise on the Baltic Sea (equilibrium values calculated after Wiesenburg and Guinasso [1979]). Abbreviations are a, southern Belt Sea; $b$, Arkona Sea; c, Bornholm Sea; d = eastern Gotland Sea; e, western Gotland Sea; and f, Oder Bight.

methane in marine sediments and anoxic marine basins [Cicerone and Oremland, 1988]. Besides this biogenic methane, seepages of thermogenic methane, which is mainly a product of petroleum formation, occurs in shelf areas [Hovland et al., 1993]. The presence of methane in surface waters of estuarine, deltaic, and shallow coastal waters may be predominantly due to the production of methane in sediments enriched in organic material, riverine sources, or shallow submarine sources [Butler et al.,
1987; de Angelis and Lilley, 1987; Ward et al., 1989; Cynar and Yayanos, 1992; Hovland et al., 1993; Jones and Amador, 1993]. The observation of methane supersaturation in the surface layer of the open ocean, away from sedimentary sources, raises some questions which remain unanswered. The reported concentrations of dissolved methane in the surface layer cannot be explained by the normal methanogenesis mechanism, which requires strictly anoxic and highly reducing conditions, or by physical transport

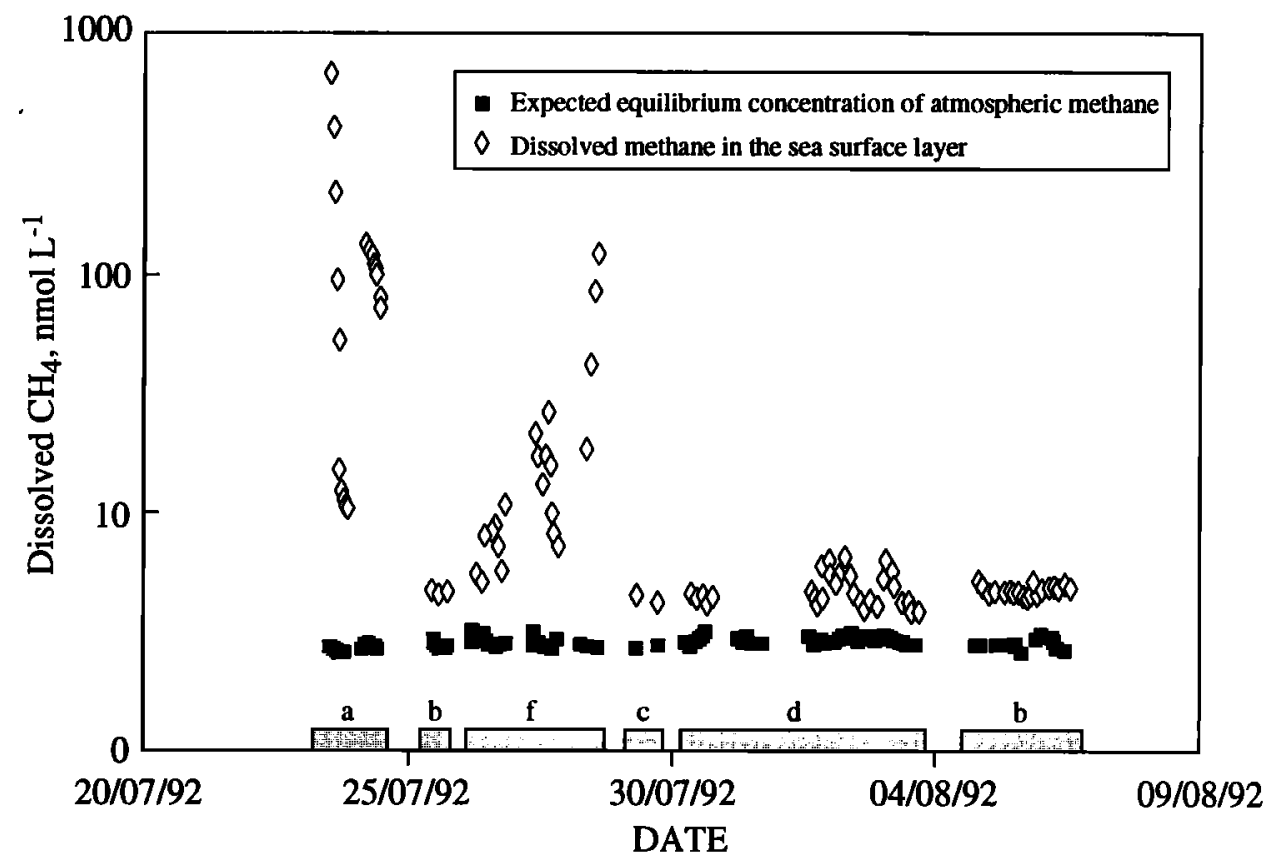

Figure 2b. Dissolved and equilibrium methane concentrations during the summer cruise on the Baltic Sea (equilibrium values calculated after Wiesenburg and Guinasso [1979]). Abbreviations are a, southern Belt Sea; $b$, Arkona Sea; c, Bornholm Sea; d = eastern Gotland Sea; e, western Gotland Sea; and f, Oder Bight. 


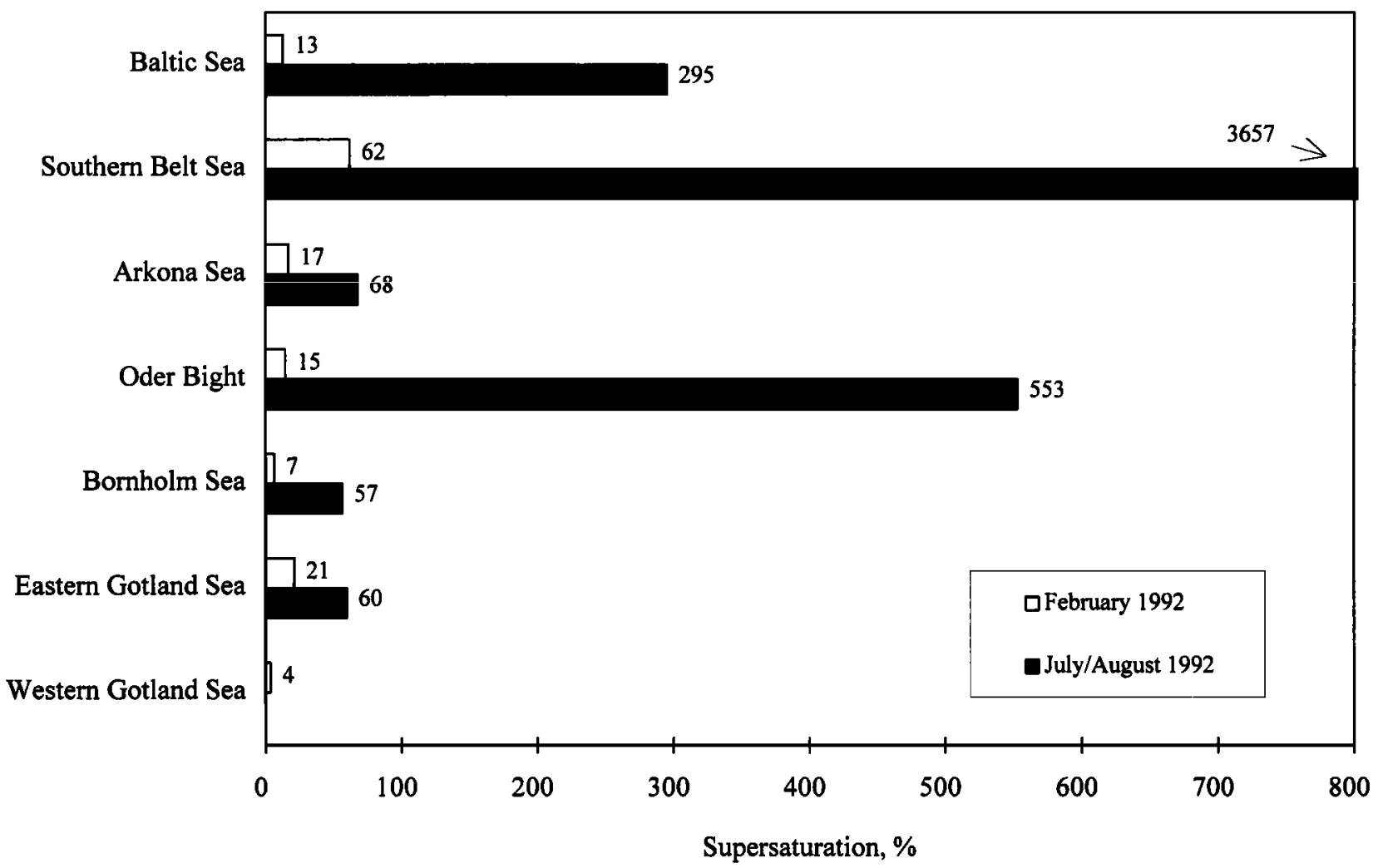

Figure 3. Overview of the mean supersaturations in various basins of the Baltic Sea.

processes. Therefore an additional in situ mode of methane production is required [Scranton and Brewer, 1977; Scranton and Farrington, 1977; Owens et al., 1991]. Various mechanisms have been discussed, e.g., formation in anoxic microniches (i.e., in decaying organic particles, faecal pellets, or zooplankton guts) or production in association with phytoplankton [Scranton and Brewer, 1977; Traganza et al., 1979; Burke et al., 1983; Conrad and Seiler, 1988; Bianchi et al., 1992; Karl and Tilbrook, 1994]. Production of methane in marine environments by a nonbiological mechanism, e.g., photoproduction, has not been observed [Wilson et al., 1970].

Methane saturation data from other shelf areas comparable with the Baltic Sea are rare (Table 3). Nevertheless, measurements in coastal regions, e.g., the southern California Bight [Cynar and Yayanos, 1992] or the estuarine-deltaic system of the Orinoco River/Gulf of Paria [Jones and Amador, 1993] show also significant seasonal variations.

Determination of the methanogenesis and methane oxidation

Table 1. Summary of Results Obtained From Various Cruises

\begin{tabular}{|c|c|c|c|c|c|}
\hline & \multirow{2}{*}{$\begin{array}{c}\text { Average } \\
\text { Atmospheric } \\
\text { Mixing Ratio, ppmv }\end{array}$} & \multirow{2}{*}{$\begin{array}{c}\text { Mean } \\
\text { Saturation, \% }\end{array}$} & \multirow{2}{*}{$\begin{array}{l}\text { Number of } \\
\text { Stations }\end{array}$} & \multicolumn{2}{|c|}{ Flux Density, nmol m $\mathrm{m}^{-2} \mathrm{~s}^{-1}$} \\
\hline & & & & Minimum & Maximum \\
\hline $\begin{array}{c}\text { Baltic Sea I } \\
\text { Feb. } 1992\end{array}$ & $1.89 \pm 0.16$ & $113 \pm 5^{a}$ & 63 & $0.11 \pm 0.2810^{-3}$ & $0.168 \pm 0.025$ \\
\hline $\begin{array}{c}\text { Baltic Sea II } \\
\text { July } 1992\end{array}$ & $1.89 \pm 0.09$ & $395 \pm 82^{\mathrm{a}}$ & 23 & $1.17 \pm 0.2310^{-3}$ & $13.89 \pm 2.99$ \\
\hline $\begin{array}{l}\text { North Sea } \\
\text { Sept. } 1992\end{array}$ & $1.92 \pm 0.10$ & $126 \pm 8$ & $117^{b}$ & $-6.6 \pm 8.010^{-3}$ & $0.117 \pm 0.032$ \\
\hline
\end{tabular}

Flux densities $F$ are from the air-sea exchange model of Liss and Merlivat [1986] as follows: $F=$ methane transfer coefficient $T_{\mathrm{CH} 4} \mathrm{x}$ $\Delta \mathrm{C} ; T_{C H 4}=0.17$ wind speed at $10-\mathrm{m}$ height $u_{10}(600 / S c)^{2 / 3}, u_{10} \leq 3.6 \mathrm{~m} \mathrm{~s}^{-1} ; T_{\mathrm{CH} 4}=\left(2.85 u_{10}-9.65\right)(600 / S c)^{1 / 2}, 3.6<u_{10} \leq 13 \mathrm{~m} \mathrm{~s}{ }^{-1} ; T_{\mathrm{CH} 4}$ $=\left(5.9 u_{10}-49.3\right)(600 / S c)^{1 / 2}, u_{10}>13 \mathrm{~m} \mathrm{~s}^{-1}$.

${ }^{\mathrm{a}}$ Values are area weighted.

${ }^{b}$ Value indicates number of measurements at the fixed station. 
Table 2. Methane Saturations of Various Basins of the Baltic Sea in Winter and Summer

\begin{tabular}{|c|c|c|c|c|c|c|}
\hline & \multicolumn{2}{|c|}{ Southern Belt Sea } & \multicolumn{2}{|c|}{ Arkona Sea } & \multicolumn{2}{|c|}{ Oder Bight } \\
\hline & Winter & Summer & Winter & Summer & Winter & Summer \\
\hline Average, $\pm 1 \sigma$ & $162 \pm 40$ & $3757 \pm 3524$ & $117 \pm 6$ & $168 \pm 10$ & $115 \pm 7$ & $653 \pm 943$ \\
\hline Maximum & $\begin{array}{c}262 \pm 105 \\
(497 \pm 110)\end{array}$ & $15,040 \pm 789$ & $128 \pm 8$ & $190 \pm 12$ & $127 \pm 8$ & $4526 \pm 273$ \\
\hline Mininum & $120 \pm 8$ & $412 \pm 119$ & $110 \pm 9$ & $151 \pm 9$ & $106 \pm 7$ & $162 \pm 9$ \\
\hline \multirow[t]{3}{*}{ Number of Stations } & 17 & 2 & 12 & 2 & 9 & 14 \\
\hline & \multicolumn{2}{|c|}{ Bornholm Sea } & \multicolumn{2}{|c|}{ Eastern Gotland Sea } & \multicolumn{2}{|c|}{ Western Gotland Sea } \\
\hline & Winter & Summer & Winter & Summer & \multicolumn{2}{|c|}{ Winter } \\
\hline Average, $\pm 1 \sigma$ & $107 \pm 3$ & 157 & $121 \pm 14$ & $160 \pm 24$ & \multicolumn{2}{|c|}{$104 \pm 2$} \\
\hline Maximum & $112 \pm 9$ & $165 \pm 11$ & $156 \pm 7$ & $215 \pm 116$ & \multicolumn{2}{|c|}{$107 \pm 7$} \\
\hline Minimum & $101 \pm 7$ & $148 \pm 10$ & $108 \pm 8$ & $131 \pm 8$ & \multicolumn{2}{|c|}{$101 \pm 8$} \\
\hline Number of Stations & 10 & 1 & 10 & 4 & \multicolumn{2}{|c|}{5} \\
\hline
\end{tabular}

All values are in percent. Parentheses indicate extreme maximum.

rates in the sediments of the brackish water ecosystem at the east coast of the Island of Rügen (southern Arkona Sea) showed that methanogenesis rates are relatively high. However, $2-68 \%$ of the produced methane is oxidized within the sediments and the methanogenesis rates depend strongly on the availability of organic matter [Berger and Heyer, 1990; Heyer et al., 1990]. Nevertheless, the observation of high summer saturations in the shallow southern Belt Sea (depths $<25 \mathrm{~m}$ ) and the Oder Bight (depths $<20 \mathrm{~m}$ ) might be caused by sedimentary production of methane and/or riverine inputs. On the last day of the

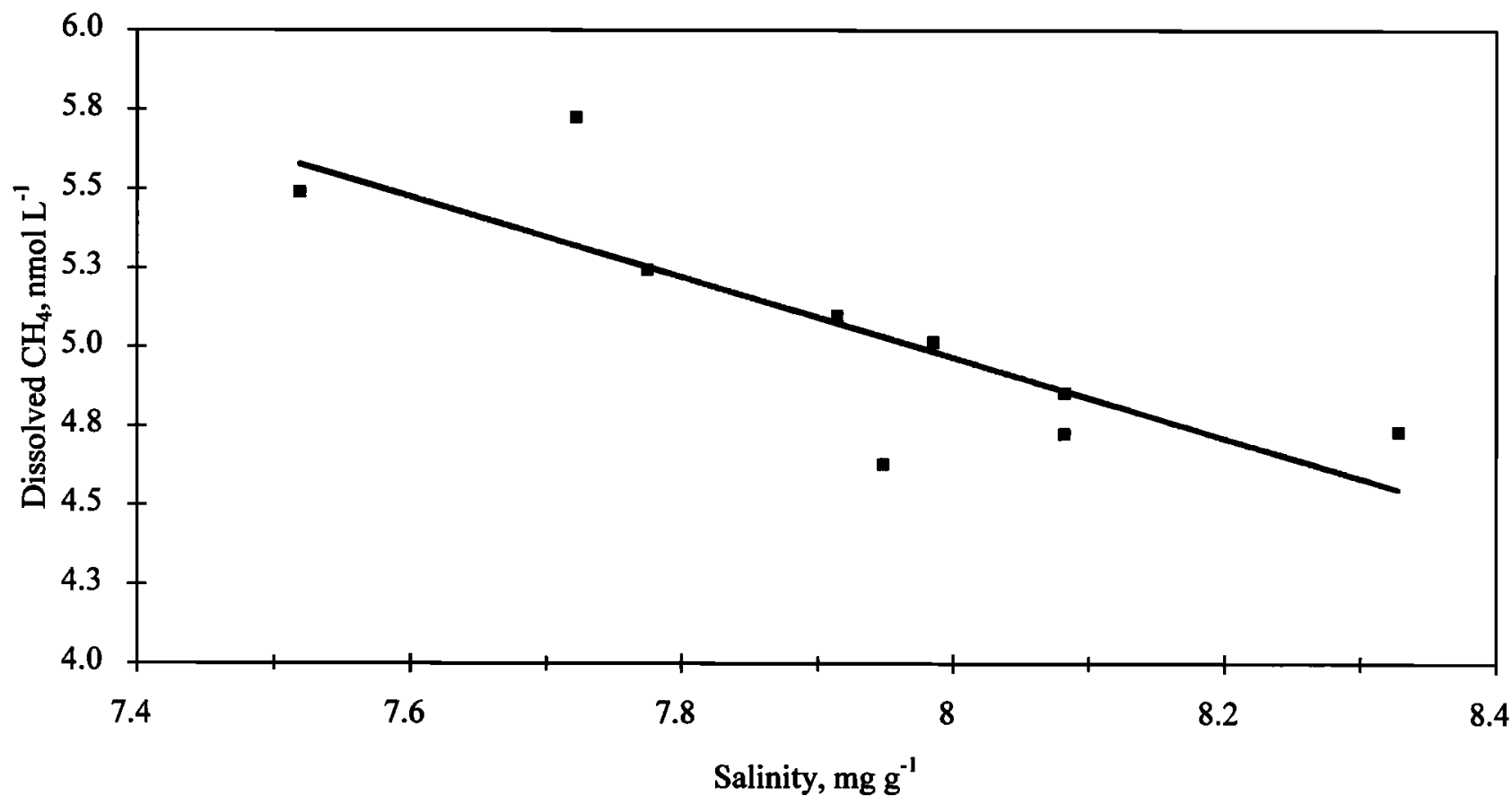

Figure 4a. Dissolved methane in the Oder Bight in February 1992; correlation coefficient $r^{2}=0.6497$ (number of samples $n=9$ ). 


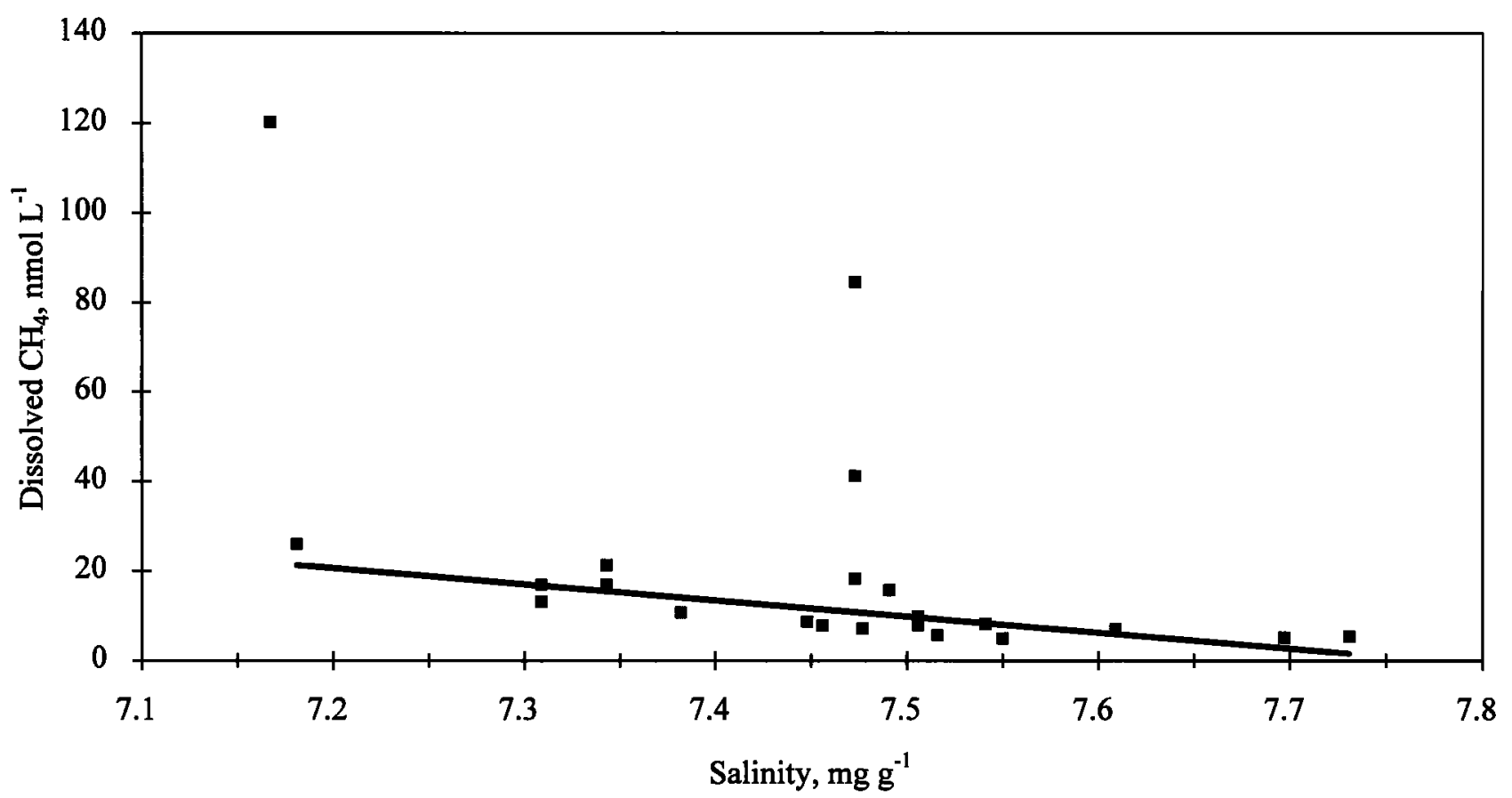

Figure 4b. Dissolved methane in the Oder Bight in July 1992; correlation coefficient $r^{2}=0.6868$ (number of samples $n=18$ ).

measurement program in the Oder Bight the wind speed increased from low $\left(1.5-7.0 \mathrm{~m} \mathrm{~s}^{-1}\right)$ to high speeds with peaks of $15.7 \mathrm{~m} \mathrm{~s}^{-1}$. At the same time, we observed at a station, which had been sampled 2 days before during low wind speeds, a considerable increase of the dissolved methane from $8.16 \pm 3.10 \mathrm{nmol} \mathrm{L}^{-1}$ to $120.2 \pm 3.16 \mathrm{nmol} \mathrm{L}^{-1}$. This might be explained by enhanced release of methane from disturbed sediments to the well-mixed water column (water depth at this station, $11 \mathrm{~m}$ ) or advection of methane-enriched water from a different source region. This temporary change of the saturation is reflected by the scatter of the data in Figure $4 \mathrm{~b}$.

Methane seeps as another possible source of dissolved methane are documented for the Kattegat and Skagerrak region [Hovland et al., 1993] and are not known for the measurement area. The slightly lower supersaturation observed in the deeper and stratified northern basins might be explained by horizontal

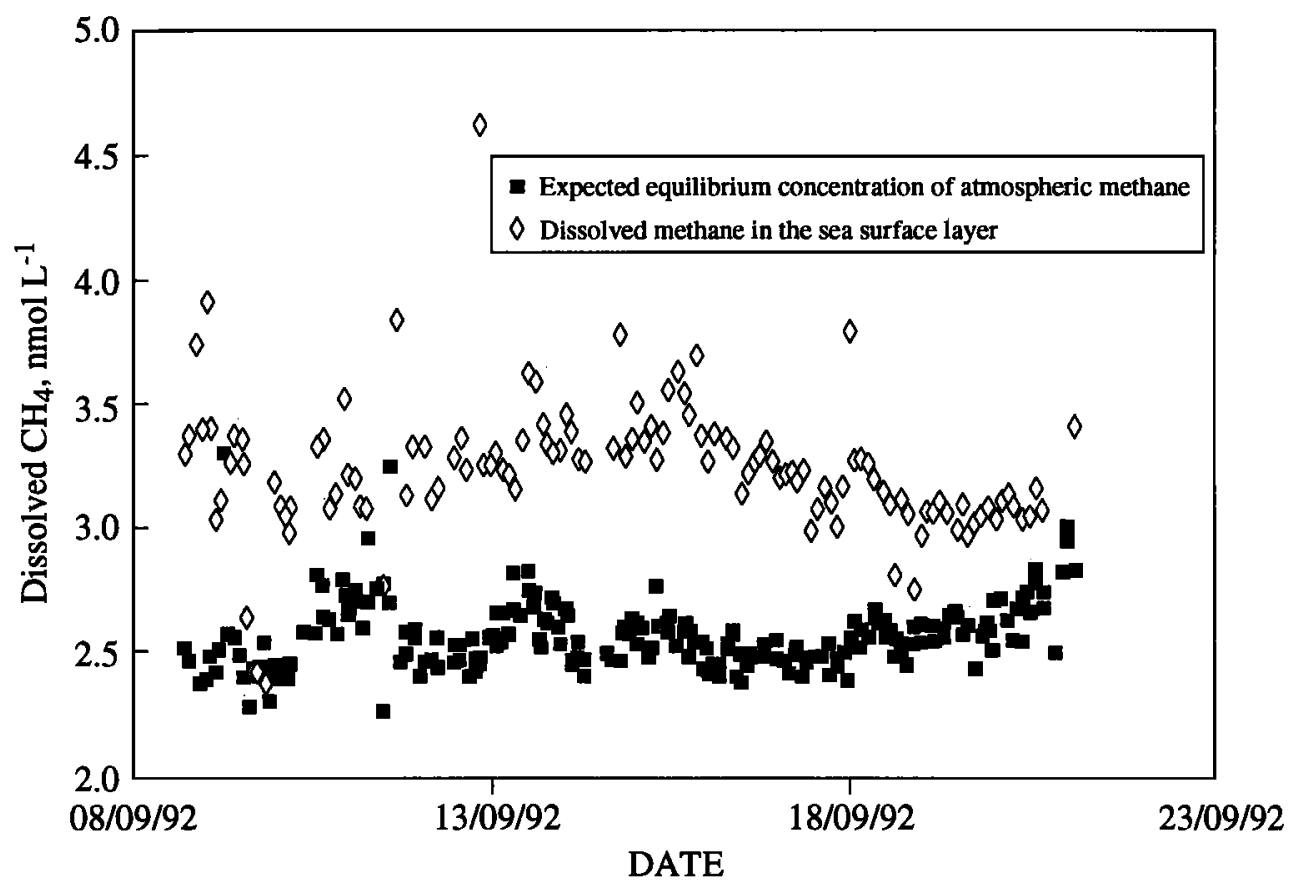

Figure 5a. Dissolved and equilibrium methane concentrations in south central North Sea (equilibrium values calculated after Wiesenburg and Guinasso [1979]). 


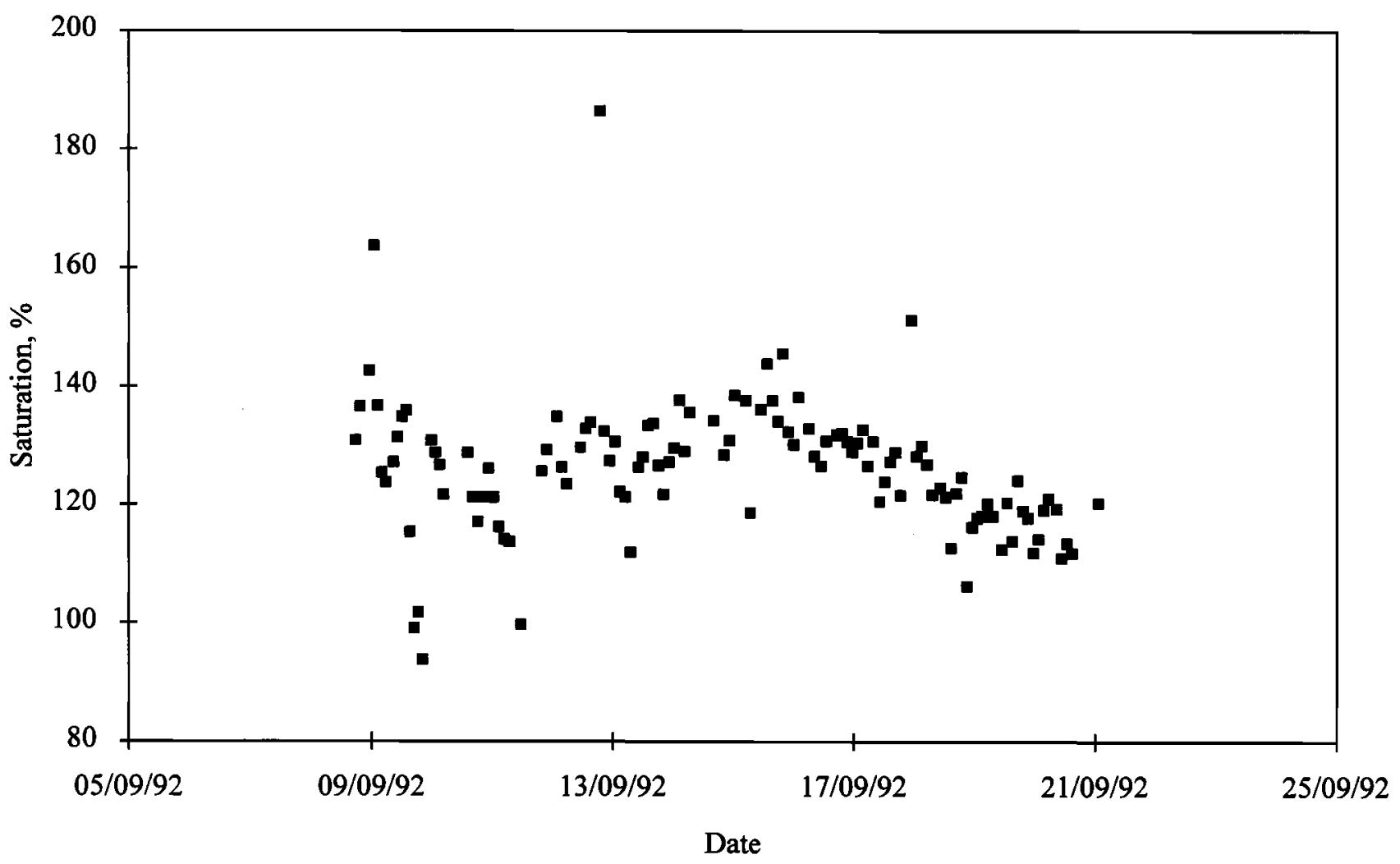

Figure 5b. Saturation of methane at the $R / P$ Nordsee in the south central North Sea.

flows of surface waters from the well-mixed shallow southern basins (southern Belt Sea, Arkona Sea) to northern basins (Bornholm Sea, Gotland Sea) in conjunction with additional riverine sources.

The saturation values observed in the south central North Sea are comparable with observations of Conrad and Seiler [1988] in the southern North Sea and the British Channel in January 1979 and October 1980. Measurements from Scranton and McShane [1991] in the southern bight of the North Sea and the plume of the Rhine and Scheldt Rivers in March 1989 ranged from 95$130 \%$ (offshore) up to $12,000 \%$ (near shore) saturation. In fall the water column around the location of the R/P Nordsee (water depth $30 \mathrm{~m}$ ) is typically well-mixed and influenced by water masses coming from the German Bight [Otto et al., 1990]. Salinity measurements during the campaign confirm this hydrographic situation. Therefore the observed saturations which were most of the time significantly higher than $100 \%$ could result from riverine sources (rivers Elbe and Weser) or release from sediments. Active methane seepages reported for the northern region of the North Sea [Hovland et al., 1993] do not influence the south central North Sea. Methane releases from oil and gas rigs which are located in the southern North Sea seem to be negligible [Scranton and McShane, 1991] and probably do not influence the waters around the R/P Nordsee.

The flux densities calculated for the three expeditions (Table 1) are in good agreement with fluxes given in the literature (Table 3). A compilation of methane measurements in marine environments (only measurements in the surface layer are considered) shows that the occurrence of methane supersaturation is not limited to biologically productive areas (i.e., estuaries, coastal zones, and upwelling areas) (Table 3).
Where no saturation value was reported, we estimated this value from the seawater concentration using (if available) the sea surface temperature and salinity and assuming an annual tropospheric growth rate of $0.8 \%$. Saturation equilibrium or undersaturation have been observed only in a few cases. Undersaturation might be the result of seasonal effects due to changes of hydrographic parameters, especially the sea surface temperature.

There is a clear trend toward higher supersaturation ratios in coastal and highly productive environments. The data listed in Table 3 indicate that most parts of the ocean act as a source for methane. One has to be aware, however, that there is a tendency to make oceanographic measurements during the spring, summer, and fall seasons. Seasonal differences can cause considerable variation in the distribution of methane in biologically productive regions (e.g., Baltic Sea), so that the present data set is likely to be biased toward the higher saturation ratios typical of the warmer seasons.

On the bases of our own results and the literature data in Table 3 we reassessed the oceanic flux of methane as the sum of regional fluxes from the different oceanic provinces of the world's oceans. Using the bathymetric classification of oceanic provinces by Menard and Smith [1966], regional annual mean methane transfer coefficients were calculated. These coefficients were derived from matrices of mean annual $\mathrm{CO}_{2}$ transfer coefficients computed with the National Center for Atmospheric Research Community Climate Model 1 (NCAR CCM1) (D. J. Erickson, private communication, 1994). Two parameterizations of the air-sea exchange were applied, the recently published stability dependent model of Erickson [1993] (hereinafter referred to as E 93) and the widely used relationship of Liss and 
Table 3. Compilation of Methane Measurements in Surface Waters of Various Marine Environments

\begin{tabular}{|c|c|c|c|c|c|}
\hline & $\begin{array}{l}\text { Saturation, } \\
\%\end{array}$ & 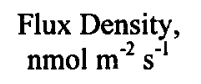 & $\begin{array}{l}\text { Number of } \\
\text { Stations }\end{array}$ & Date & Reference \\
\hline \multicolumn{6}{|c|}{ Estuaries } \\
\hline Lake Nitinat & 1900 & & 1 & Nov. 1967 & Lamontagne et al. [1973] \\
\hline Chesapeake Bay & $1100-1700$ & & 6 & June 1968 & Swinnerton et al. [1969] \\
\hline Saanich Inlet & 1300 & & 1 & June 1978 & Lilley et al. [1982] \\
\hline Saanich Inlet & 1300 & & 1 & July, Aug. 1978 & Bullister et al. [1982] \\
\hline Alsea Bay & $300-29000$ & 2.09 & 7 & $1979-1982$ & de Angelis and Lilley [1987] \\
\hline Yaquina Bay & $300-11600$ & $(0.03-15.2)$ & 9 & & \\
\hline Salmon Bay & $5200-12400$ & & 1 & & \\
\hline Yaquina Bay & $100-5500^{\mathrm{a}}$ & $1.41-3.28$ & 10 & $1983-1984$ & Butler et al. [1987] \\
\hline Saanich Inlet & 1200 & 0.03 & 1 & 1983, Aug. 1986 & Ward et al. [1989] \\
\hline Pettaquamscutt River estuary & $8000-11000$ & $\begin{array}{l}4.70-49.19^{b} \\
0.217-3.906^{c}\end{array}$ & 8 & $\begin{array}{l}\text { Aug. 1989, Aug. } \\
\text { 1990, May, June, } \\
\text { Aug. } 1991\end{array}$ & Scranton et al. [1993] \\
\hline Hudson River estuary & $2500-7200$ & $3.54-4.48$ & 12 & March, Aug. 1991 & de Angelis and Scranton [1993] \\
\hline Amvrakikos Bay, Greece & $\begin{array}{c}522 \\
146-974\end{array}$ & 0.167 & cont. & July 1993 & H. W. Bange et al. (1994) \\
\hline \multicolumn{6}{|c|}{ Coastal and Shelf } \\
\hline Red Sea & 170 & & 1 & June 1967 & Lamontagne et al. [1973] \\
\hline Black Sea & 180 & & 1 & May 1967 & \\
\hline Southern Beaufort Sea & $100-790^{\mathrm{a}}$ & & 18 & Aug. 1974 & Macdonald [1976] \\
\hline & $85-260^{a}$ & & 25 & Aug. 1975 & \\
\hline Northwestern Gulf of Mexico & $120-23900$ & & 50 & $1975-1976$ & Brooks et al. $[1981]$ \\
\hline Western Mediterranean & 260 & & 1 & July 1978 & Traganza et al. [1979] \\
\hline Philippine Sea & $120,790^{\mathrm{a}}$ & & 2 & Nov., Dec. 1984 & Belviso et al. $[1987]$ \\
\hline North Molucca Sea & $380^{\mathrm{a}}$ & & 1 & & \\
\hline Celebes Basin & $700,3100^{2}$ & & 2 & & \\
\hline Gulf of Aden & $140-170^{\mathrm{a}}$ & & 4 & July 1987 & Jean-Baptiste et al. [1990] \\
\hline Western Sagami Bay, Japan & $150^{\mathrm{a}}$ & & 1 & Feb. 1988 & Gamo et al. $[1988]$ \\
\hline Black Sea & $200-500$ & 0.31 & 1 & July 1988 & Reeburgh et al. [1991] \\
\hline Southern North Sea & $95-12000$ & $0.07-700$ & 75 & March 1989 & Scranton and McShane [1991] \\
\hline NW Mediterranean Sea & 477 & & 1 & Oct. 1989 & Lambert and Schmidt [1993] \\
\hline & $181-2625$ & & & May 1990 & \\
\hline Southern California Bight & $85-4600^{2}$ & & 70 & Nov. 1989 & Cynar and Yayanos [1992] \\
\hline & $125-42000^{\mathrm{a}}$ & & & March 1990 & \\
\hline Southern California Bight & $\begin{array}{c}130-430^{\mathrm{a}} \\
150^{\mathrm{a}}\end{array}$ & $0.04,1.7$ & 1 & $\begin{array}{l}\text { Jan. } 1990 \\
\text { July } 1990\end{array}$ & Ward [1992] \\
\hline $\begin{array}{l}\text { Sea of Okhotsk, ice covered } \\
\text { ice free }\end{array}$ & $\begin{array}{l}\leq 7500 \\
\geq 1000\end{array}$ & 1.39 & & $\begin{array}{l}\text { March 1991, } \\
\text { summer } 1992\end{array}$ & Lammers [1993] \\
\hline \multicolumn{6}{|c|}{ Oligotrophic and Transitional } \\
\hline Western tropical North & $130(120-150)$ & & 25 & May 1970 & Lamontagne et al. [1973] \\
\hline Atlantic & $130(120-150)$ & & 50 & June 1970 & \\
\hline Eastern tropical North Pacific & $140(120-150)$ & & 70 & Aug. 1971 & \\
\hline Norwegian Greenland Sea & $130(120-170)$ & & 23 & Aug. 1971 & \\
\hline Greenland Ice Pack & $130(120-130)$ & & 6 & May 1971 & \\
\hline Sargasso Sea & $140(130-140)$ & & 3 & & \\
\hline Caribbean Sea & $150(120-160)$ & & 4 & & \\
\hline Cariaco Trench & 160 & & 1 & & \\
\hline Gulf of Mexico & 130 & & 1 & May 1967 & \\
\hline Mediterranean Sea & 130 & & 1 & May 1967 & \\
\hline \multicolumn{6}{|l|}{ Eastern Mediterranean Sea } \\
\hline Atlantic Ocean, Sargasso Sea & 100 & & 6 & June 1968 & Swinnerton et al. [1969] \\
\hline South Pacific, Antarctica & 100 & & 16 & Feb. 1971 & Williams and Bainbridge [1973] \\
\hline North, South Pacific & 130 & $\leq 0.08$ & 10 & Nov., Dec. 1972 & Lamontagne et al. [1974] \\
\hline Antarctica, ice covered & 80 & & & & \\
\hline $\begin{array}{l}\text { Western subtropical North- } \\
\text { Atlantic }\end{array}$ & $148-231$ & 0.03 & 8 & Feb. 1975 & Scranton and Brewer [1977] \\
\hline Eastern tropical North Pacific & $100-180$ & & 9 & May 1979 & Burke et al. [1983] \\
\hline Atlantic Ocean & $110 \pm 5$ & 0.01 & cont. & $\begin{array}{l}\text { Jan., Feb. } 1979 \text {, } \\
\text { Oct., Nov. } 1980\end{array}$ & Conrad and Seiler [1988] \\
\hline Mediterranean Sea & $110-200^{a}$ & & 10 & Aug., Sept. 1980 & Lavoie et al. [1982] \\
\hline
\end{tabular}


Table 3. (continued)

\begin{tabular}{|c|c|c|c|c|c|}
\hline & $\begin{array}{c}\text { Saturation, } \\
\%\end{array}$ & $\begin{array}{l}\text { Flux Density, } \\
\text { nmol m } \mathrm{m}^{-2} \mathrm{~s}^{-1}\end{array}$ & $\begin{array}{l}\text { Number of } \\
\text { Stations }\end{array}$ & Date & Reference \\
\hline Mid-Atlantic Ridge $12 \mathrm{~N}-15 \mathrm{~N}$ & $100-130^{\mathrm{a}}$ & & 3 & Feb., March 1985 & Charlou et al. [1988] \\
\hline Loihi Seamount, Hawaii & $80^{\mathrm{a}}$ & & 1 & Sept. 1985 & Gamo et al. [1987] \\
\hline Cariaco Basin & 104 & 0.003 & 1 & Jan., Feb. 1986 & Ward et al. [1987] \\
\hline East Pacific Rise $11 \mathrm{~N}-13 \mathrm{~N}$ & $120,110^{\mathrm{a}}$ & & 2 & Dec. 1986 & Charlou et al. [1991] \\
\hline Northeast Atlantic $47 \mathrm{~N}, 20 \mathrm{~W}$ & $125 \pm 9$ & 0.020 & cont. & April, May 1992 & $\begin{array}{l}\text { S. Rapsomanikis et al. } \\
\text { (unpublished } \\
\text { data 1992) }\end{array}$ \\
\hline Aegean Sea & $176 \pm 16$ & 0.021 & cont. & July 1993 & H. W. Bange et al. (1994) \\
\hline Northwestern Levantine Basin & $118 \pm 7$ & 0.035 & & & \\
\hline Eastern Ionian Sea & $135 \pm 24$ & 0.040 & & & \\
\hline \multicolumn{6}{|c|}{ Upwelling } \\
\hline Arabian Sea & 170 & & 1 & June 1967 & Lamontagne et al. $[1973]$ \\
\hline Walvis Bay & $200-30000$ & & 9 & $\begin{array}{l}\text { Dec. } 1975- \\
\text { Jan. } 1976\end{array}$ & Scranton and Farrington [1977] \\
\hline Subtropical North Atlantic & 287 & & 1 & July 1978 & Traganza et al. [1979] \\
\hline Equatorial Pacific & $110-120$ & & cont. & $\begin{array}{l}\text { July } 1979 \text { - } \\
\text { June } 1980\end{array}$ & $\begin{array}{l}\text { R. F. Weiss (personal } \\
\text { communication, 1981) }\end{array}$ \\
\hline Equatorial Pacific & $105 \pm 2$ & 0.005 & cont. & Feb., March 1990 & Bates et al. [1993] \\
\hline Arabian Sea & $\begin{array}{c}192 \\
(157-286)\end{array}$ & $0.05-0.16$ & 13 & Sept., Oct. 1986 & Owens et al. [1991] \\
\hline Peruvian Coast & $86-438$ & $-0.006-0.097$ & 7 & March, April 1992 & Lammers and Suess [1994] \\
\hline
\end{tabular}

Numbers in parentheses indicate ranges. Cont. indicates continous measurements.

${ }^{\text {a }}$ Values are extrapolated; for details see text.

${ }^{b}$ Values are measured.

${ }^{c}$ Values are calculated.

${ }^{d}$ Reference is The Aegean Sea as a source of atmospheric nitrous oxide and methane, submitted to Marine Chemistry, 1994.

Merlivat [1986] (hereinafter referred to as LM 86). The resulting matrices were plotted and analyzed graphically to derive the mean $\mathrm{CO}_{2}$ regional transfer coefficients. These values were corrected according to the Schmidt numbers $S c$ of methane and carbon dioxide at a salinity of $35 \%$

$$
T_{\mathrm{CH} 4}=T_{\mathrm{CO} 2}\left(\mathrm{Sc}_{\mathrm{CO} 2} / \mathrm{Sc}_{\mathrm{CH} 4}\right)^{0.5}
$$

where $T$ is the transfer coefficient.

The Schmidt numbers for $\mathrm{CO}_{2}$ were calculated with the equation given by Erickson [1993]. Annual mean sea surface temperatures for each oceanic province were derived from monthly data fields which were used as input for the calculations of the transfer coefficients with the NCAR CCM1 (D. J. Erickson, personal communication, 1994). The resulting methane transfer coefficients $T_{\mathrm{CH}_{4}}$ and sea surface temperatures are listed in Table 4. Since the spatial resolution of the NCAR CCM1 was $2.8^{\circ} \times 2.8^{\circ}$ latitude-longitude (i.e., 8192 grid points), some of the oceanic provinces were characterized by less than 10 grid points. Therefore the mean values of these provinces (e.g., Gulf of California, Baltic Sea, Red Sea etc.) have to be regarded as uncertain. Additional uncertainties in the wind and temperature fields and the applied equations used in the CCM1 introduce an error for the transfer coefficient of at least 50\% [Erickson, 1988].

Regional methane fluxes $S_{o}$ across the air-sea interface were calculated with the equation

$$
S_{o}=A T_{C_{4}}\left(S R C_{a}-C_{a}\right)
$$

where $T_{\mathrm{CH} 4}$ is the methane transfer coefficient (listed in Table 4),
$S R$ is the saturation ratio ( $S R=$ saturation/100), $A$ is the area of the oceanic province, and $C_{a}$ is the equilibrium seawater concentration for a tropospheric mixing ratio of $1.7 \mathrm{ppmv}$ calculated with the equation of Wiesenburg and Guinasso [1979] with a salinity of $35 \%$ (except for the estuary province where we used $18 \%$ ) and the annual sea surface temperature of the oceanic province.

Following the concept of the regional transfer coefficients, we tried to compute the corresponding regional methane saturation values. Again we used the classification of Menard and Smith [1966], but in this case we additionally distinguished between the shelf and the open ocean region of an oceanic province. (Menard and Smith [1966] defined the shelf region as the whole region from the shoreline to the base of the steep continental slope.) The methane saturation values were taken from the overview in Table 3. If saturation values were reported for an open ocean or a shelf region, then we calculated the mean saturation value applying the following procedure: when different types of saturation values (i.e., mean values, ranges, and single values) existed, we decided to give the reported mean values high weight and the ranges low weight. In the cases of reported ranges we calculated the mean by using the maximum and the minimum values when more than one range was given for the same region. When only single values for a region were available, we took the average. Oceanic regions represented only by three single values or less were not considered. Table 5 gives an overview of the flux densities and the resulting sea-to-air fluxes from the various oceanic provinces. Because saturation data were only available for $70 \%$ of the world's ocean area, we extrapolated the missing fluxes using area-weighted saturation values for the open ocean 
Table 4. Regional Sea Surface Temperatures (SST) and Methane Transfer Coefficients $\mathrm{T}_{\mathbf{C H} 4}$

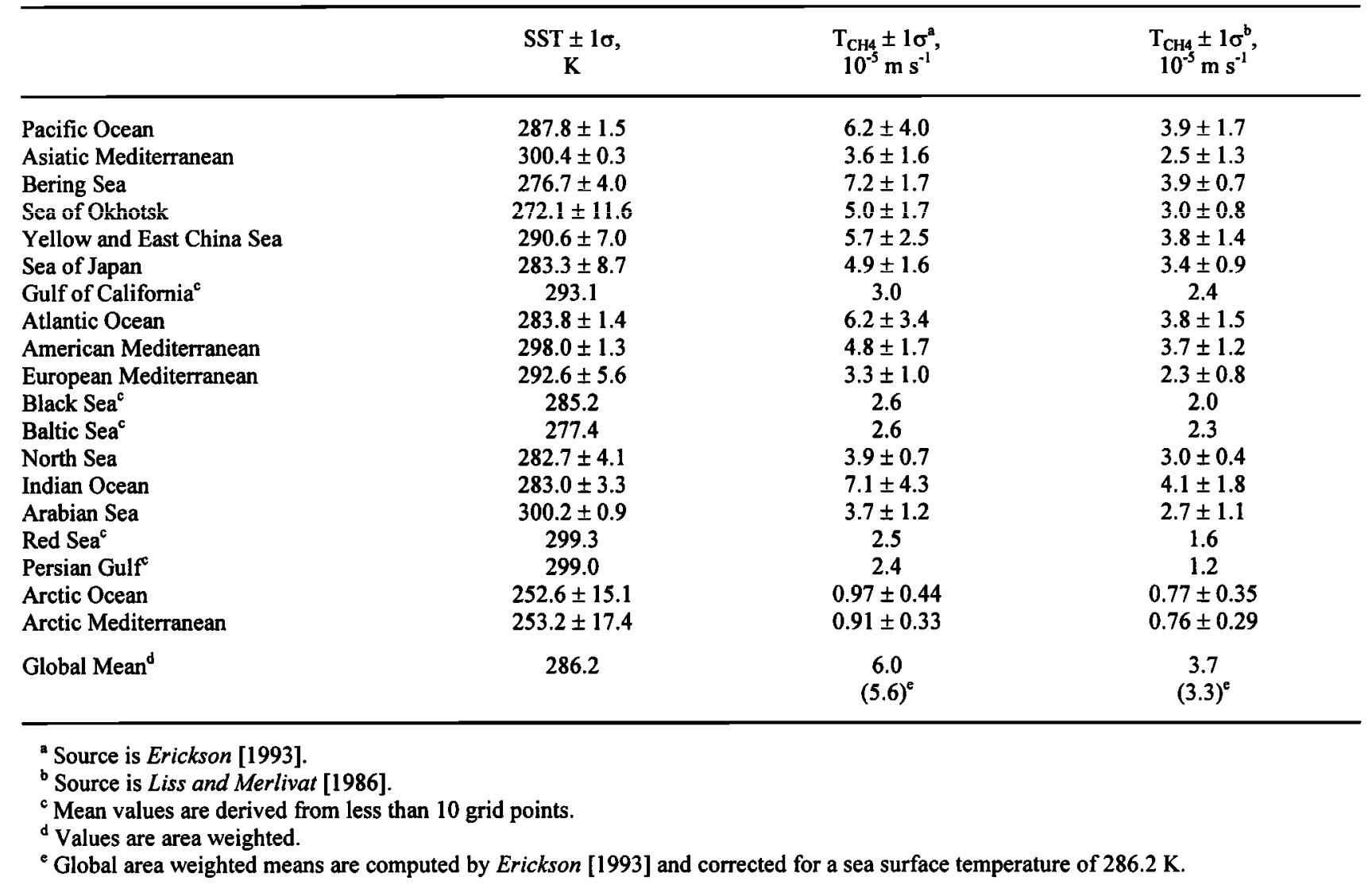

(120\%) and the shelf regions (395\%). Introducing area-weighted mean transfer coefficients of $6.210^{-5} \mathrm{~m} \mathrm{~s}^{-1}$ (E 93) and $3.710^{-5}$ $\mathrm{m} \mathrm{s}^{-1}$ (LM 86), we estimated the oceanic fluxes for the missing open ocean and shelf regions.

In Table 5 we show separately the estuarine region which represents an important part of the oceanic methane source. The sum of the regional fluxes yielded global oceanic fluxes of 17.8 $\mathrm{Tg} \mathrm{CH}_{4} \mathrm{yr}^{-1}$ (E 93) and 10.9 $\mathrm{Tg} \mathrm{CH}_{4} \mathrm{yr}^{-1}$ (LM 86) (Table 5). The discrepancy between the two values shows the great uncertainties which are introduced by different air-sea exchange models. Transfer coefficients derived from ${ }^{14} \mathrm{C}$ measurements and dualtracer experiments indicated that calculations based on the approach of Liss and Merlivat [1986] seem to underestimate the gas transfer coefficient [Wanninkhof et al., 1993]. Thus our calculations suggest that the global oceanic methane flux lies in the range from 11 to $18 \mathrm{Tg} \mathrm{CH}_{4} \mathrm{yr}^{-1}$ considering the result of the Liss and Merlivat [1986] model as a lower limit and the result of the Erickson model [1993] as a upper limit. This is still in reasonable agreement with the widely used estimation of Cicerone and Oremland [1988] (mean, $10 \mathrm{Tg} \mathrm{CH}_{4} \mathrm{yr}^{-1}$; range, 5$20 \mathrm{Tg} \mathrm{CH}_{4} \mathrm{yr}^{-1}$ ) which is based mainly on the calculations of Ehhalt [1974] and an estimation published by Khalil and Rasmussen [1983] (13 $\left.\mathrm{Tg} \mathrm{CH}_{4} \mathrm{yr}^{-1}\right)$. A recently published flux estimation of $10 \mathrm{Tg} \mathrm{CH} / \mathrm{a}$ [Lambert and Schmidt, 1993] is identical to the mean value of Cicerone and Oremland [1988]. Despite the fact that shelf regions (including the estuaries) occupy only about $16 \%$ of the world's ocean area they contribute approximately $75 \%$ to the global oceanic methane emissions. Nevertheless, estimations of the oceanic flux of methane are generally suffering from the poor database and the neglect of the seasonal variability of the methane saturation in the seawater surface layer. A further uncertainty is caused by the fact that about $5 \%$ of the world's ocean (e.g., Arctic Ocean, Arctic Mediterranean, Sea of Okhotsk, Bering Sea, Baltic Sea, etc.) are temporarily covered by ice, and therefore no exchange of methane between the water and the atmosphere occurs during this period.

\section{Model calculations}

Despite the fact that the marine methane emissions play only a modest role in the global budget the following question arises: How does the oceanic flux respond to an increasing tropospheric methane mixing ratio? From ice core measurements it is known that since the beginning of the industrialization (approximately 150 years ago), the tropospheric methane mixing ratio has increased from $0.8 \mathrm{ppmv}$ to $1.7 \mathrm{ppmv}$ [Houghton et al., 1990]. Reliable measurements of dissolved methane are available only since the late 1960s (see Table 3). Moreover, no continuous measurements of dissolved methane in representative areas of the world's ocean are available, so that no conclusions for the temporal development of the oceanic flux can be drawn.

Our aim was to model the time dependent variation of the flux density across the ocean-atmosphere interface over a time of 100 years to show the effect of increasing tropospheric methane on the marine methane emissions. The model consists of the following three coupled reservoirs (Figure 6): (1) mixed surface layer of the ocean, 
Table 5. $\mathrm{CH}_{4}$ Saturations and Fluxes for Various Oceanic Provinces

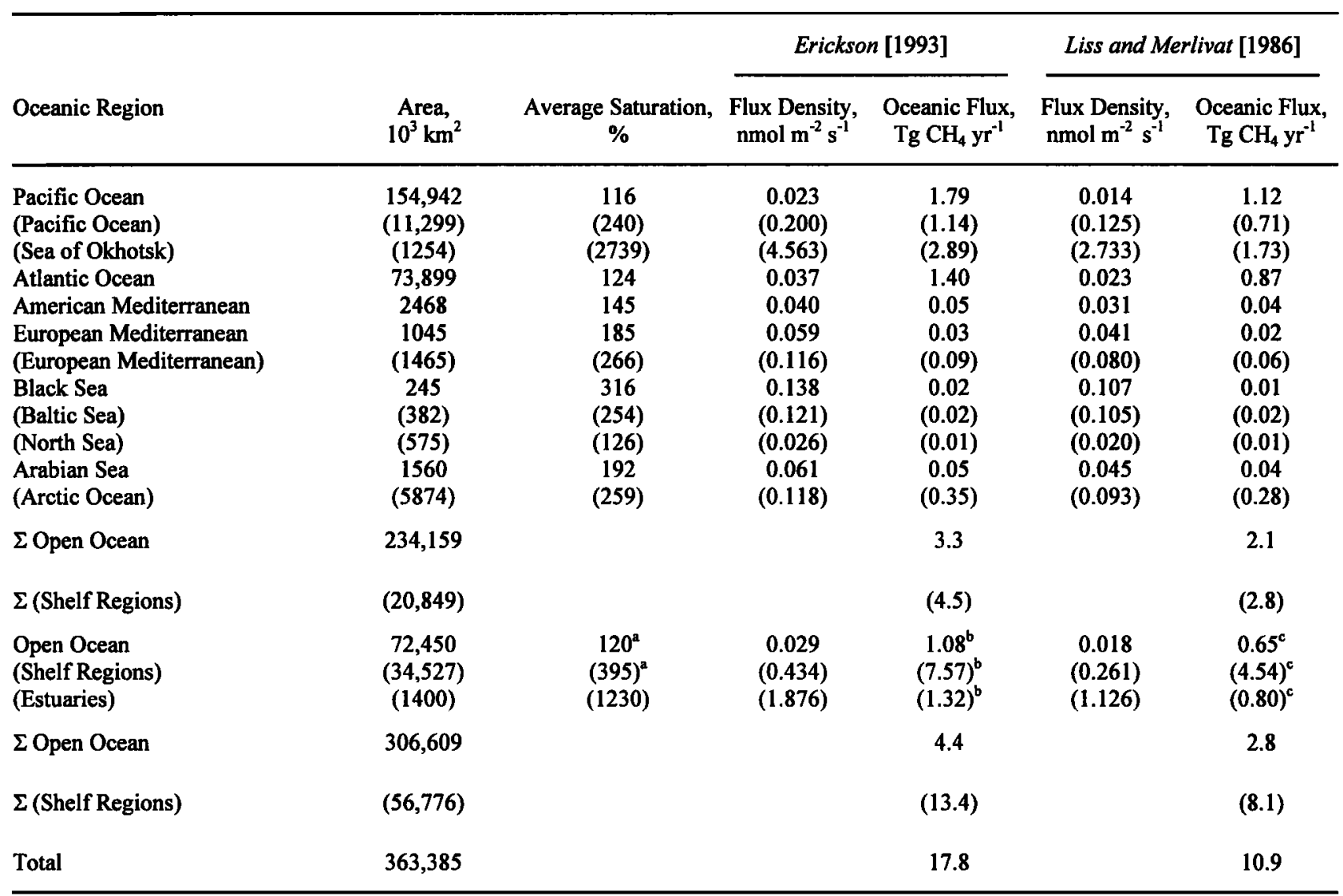

Shelf regions are given in parentheses. All "area" data are from Menard and Smith [1966] except North Sea, Otto et al. [1990]; Arabian Sea, Owens et al. [1991]; and estuaries, Woodwell [1980]. The $\Sigma$ indicates sum. Flux densities $F$ and oceanic fluxes $S_{o}$ are calculated as follows: $F=T_{C H 4} \times\left(S R \times C_{a}-C_{a}\right)$, where $T_{C H 4}$ is gas transfer coefficient; $S R$, saturation ratio (saturation/100); and $C_{o}$, equilibrium water concentration based on the tropospheric methane mixing ratio (1.7 parts per million by volume); $S_{o}=F \times A$, where $A$ is area of the oceanic province.

${ }^{2}$ Value is area weighted extrapolation.

${ }^{b}$ Value is calculated with global area weighted transfer coefficient $T_{C H 4}=6.210^{-5} \mathrm{~m} \mathrm{~s}^{-1}$ Erickson [1993].

${ }^{c}$ Value is calculated with global area weighted transfer coefficient $T_{C H 4}=3.710^{-5} \mathrm{~m} \mathrm{~s}^{-1}$ Liss and Merlivat [1986].

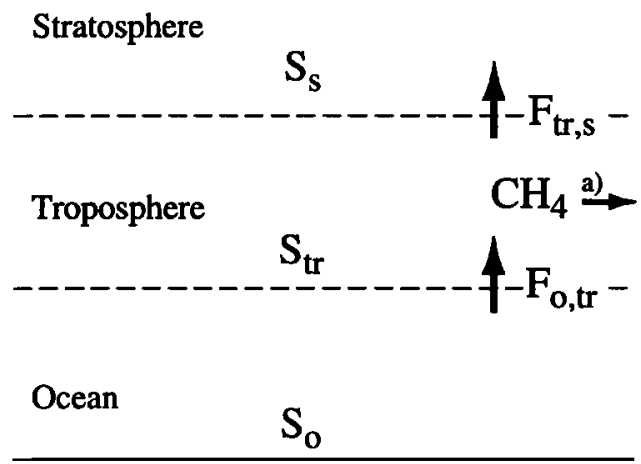

Figure 6. Scheme of the three-layer model; $F_{o, t r}$ is flux density between the ocean $o$ and troposphere $t r ; F_{t r, s}$, flux density between the troposphere and stratosphere $s ; S_{o}$, oceanic source; $S_{t \text { n }}$ tropospheric (i.e., terrestrial) source; and $S_{s,}$ stratospheric sink. The label "a" indicates consuming reaction $\mathrm{CH}_{4}+\mathrm{OH}$ $\longrightarrow \mathrm{CH}_{3}+\mathrm{H}_{2} \mathrm{O}$.

$$
\begin{gathered}
\frac{d C_{o}}{d t}=-\frac{F_{o, t r}}{H_{o}}+S_{o} \\
F_{o, t r}=T_{o, t r}\left(C_{w}-C_{a}\right),
\end{gathered}
$$

(2) troposphere,

$$
\frac{d C_{t r}}{d t}=\frac{F_{o, t r}}{H_{o}}-\frac{F_{t r, s}}{H_{t r}}+S_{t r}-K C_{(O H)} C_{t r},
$$

and (3) stratosphere:

$$
\begin{gathered}
\frac{d C_{s}}{d t}=\frac{F_{t r, s}}{H_{s}}-S_{s} \\
F_{t r, s}=T_{t r, s}\left(C_{t r}-C_{s}\right)
\end{gathered}
$$

where $o$ is ocean; $t r$, troposphere; $s$, stratosphere; $w$, dissolved methane; $a$, dissolved equilibrium methane calculated from the atmospheric value; $C$, methane concentration; $H$, height of the reservoir; $C_{(\mathrm{OH})}$, mean tropospheric $\mathrm{OH}$ concentration, and $K$, mean reaction constant for $\mathrm{CH}_{4}+\mathrm{OH} \longrightarrow \mathrm{CH}_{3}+\mathrm{H}_{2} \mathrm{O}$. 
Table 6. Parameters for the Three-Layer Model

\begin{tabular}{|c|c|c|}
\hline & Model Input & Range \\
\hline Height of ocean surface mixed layer ${ }^{a}, m$ & 70 & \pm 25 \\
\hline Height of troposphere, $\mathrm{m}$ & 11,000 & - \\
\hline Height of stratosphere, $\mathrm{m}$ & 21,000 & - \\
\hline Oceanic source ${ }^{\mathrm{b}}, \mathrm{Tg} \mathrm{CH}_{4} \mathrm{yr}^{-1}$ : & 14 & $11-18$ \\
\hline Terrestrial source ${ }^{c}, \mathrm{~T}_{\mathrm{g}} \mathrm{CH}_{4} \mathrm{yr}^{-1}$ & 500 & \pm 100 \\
\hline Stratospheric sink $\mathrm{c}^{\mathrm{c}}, \mathrm{Tg} \mathrm{CH} \mathrm{CHr}^{-1}$ & 10 & \pm 5 \\
\hline Preindustrial mixing ratio, ppmv & $0.8^{\mathrm{d}}$ & $\pm 0.06^{\mathrm{e}}$ \\
\hline Reaction rate with $\mathrm{OH}^{f}, 10^{-21} \mathrm{~m}^{3} \mathrm{~s}^{-1}$ molecules ${ }^{-1}$ & 2.49 & $0.93-42.8$ \\
\hline Globally averaged $\mathrm{OH}$ concentration ${ }^{\mathrm{g}}, 10^{11}$ molecules $\mathrm{m}^{-3}$ & 8.7 & \pm 1.0 \\
\hline Transfer coefficient ocean-troposphere ${ }^{\mathrm{h}}, 10^{-5} \mathrm{~m} \mathrm{~s}^{-1}$ & 5 & $3.7-6.0$ \\
\hline Transfer coefficient troposphere-stratosphere ${ }^{i}, 10^{-6} \mathrm{~m} \mathrm{~s}^{-1}$ & 6 & - \\
\hline
\end{tabular}

${ }^{a}$ Source is Li et al. [1984].

${ }^{b}$ Source is this paper (see Table 5).

c Source is Crutzen [1991].

${ }^{\mathrm{d}}$ Source is Houghton et al. [1990].

' Source is Rasmussen and Khalil [1984].

${ }^{\mathrm{f}}$ Source is Vaghjiani and Ravishankara [1991].

${ }^{\mathrm{g}}$ Source is Prinn et al. [1992].

${ }^{\mathrm{h}}$ Source is this paper (see Table 4).

'This is a fitted parameter.

$F_{o, r}$ represents the flux density between the ocean and the troposphere, while $F_{t r, s}$ is the flux density between the troposphere and the stratosphere. Analogical to this, $T_{o, \text { ir }}$ stands for the gas transfer coefficient at the ocean/troposphere interface and $T_{t r, s}$ is an arbitrarily chosen model parameter (without physical meaning) at the troposphere/stratosphere interface. $S_{t r}$ is the tropospheric source term which is equal to the sum of the terrestrial sources, and $S_{s}$ represents the stratospheric sink.

We introduced the mean of the two reassessed global oceanic fluxes ( $14 \mathrm{Tg} \mathrm{CH}_{4} \mathrm{yr}^{-1}$ ), and assumed it to be equal to the oceanic production term $S_{o}$. The in situ production or destruction (e.g., methane oxidation) rates for oceanic methane are not incorporated explicitly because these mechanisms are still unknown and poorly quantified. Methane oxidation is clearly too slow [Jones, 1991; Ward, 1992; Jones and Amador, 1993] to

Table 7. Summary of the Model Scenarios

\begin{tabular}{cccc}
\hline Scenario & $\begin{array}{c}\text { Modulation of } \\
\text { Terrestrial Source } \\
\text { Function } S_{t r}\end{array}$ & $\begin{array}{c}\text { Resulting Annual } \\
\text { Tropospheric } \\
\text { Growth Rate }\end{array}$ & $\begin{array}{c}\text { Trend of } \\
\text { Resulting } \\
\text { Dissolved } \\
\text { Methane }\end{array}$ \\
\hline A & constant & none, 0\% $\mathrm{yr}^{-1}$ & constant \\
B & $\sim t$ & linear, 0.7 \% yr-1 & constant \\
C & $\sim t+t^{2}$ & accelerated & increasing \\
D & $\sim t-t^{2}$ & decelerated & decreasing \\
\hline
\end{tabular}

The stratospheric sink and the oceanic source remain constant, $t$ is time term. cause a significant effect on the distribution in the surface layer of the most parts of the world's oceans. A constant oceanic methane source can reasonably be assumed because the production is controlled by ecological parameters, which are independent of atmospheric methane concentration, and because the ventilation to the atmosphere (timescale of days to weeks) dominates over the biological sinks (timescale of years) [Jones, 1991; Ward, 1992; Jones and Amador, 1993]. All input parameters for the model are summarized in Table 6 .

The model starts with the preindustrial tropospheric mixing ratio of $0.8 \mathrm{ppmv}$ and immediately includes all sources with a source strength of $341 \mathrm{Tg} \mathrm{CH}_{4} \mathrm{yr}^{-1}$, which is arbitrarily chosen, but we have no information about the time variation of the sources during the last 100 years. Four scenarios reflecting different time dependencies of the increase of the tropospheric methane have been modeled. The various time dependencies of the tropospheric increase were obtained by modulating the terrestrial source function $S_{t r}$. with a linear and a quadratic time term (Table 7). Scenario B was modulated to yield after 100 years a source strength of about $500 \mathrm{Tg} \mathrm{CH}_{4} \mathrm{yr}^{-1}$, which is in good agreement with a budget calculation of Crutzen [1991]. Concentrations of dissolved methane were calculated from the tropospheric concentration value using the equation of Wiesenburg and Guinasso [1979] with a mean salinity (35\%) and the mean temperature of the world's ocean surface waters (Table 4). The reaction constant of the consuming reaction was averaged for the tropospheric temperature gradient.

The model results are illustrated in Figures 7a-7d, which show the tropospheric (Figure 7a) and dissolved methane (Figure 7b), and the resulting ocean-atmosphere flux densities (Figure 7c) and saturations (Figure 7d). The concentrations of dissolved methane in the mixed layer follow closely the trends of the tropospheric methane (Figure $7 \mathrm{~b}$ ). In the case of no increase or linear increase of the tropospheric methane (scenarios $A$ and $B$ ) the flux densities reach a constant value (i.e., steady state conditions) 

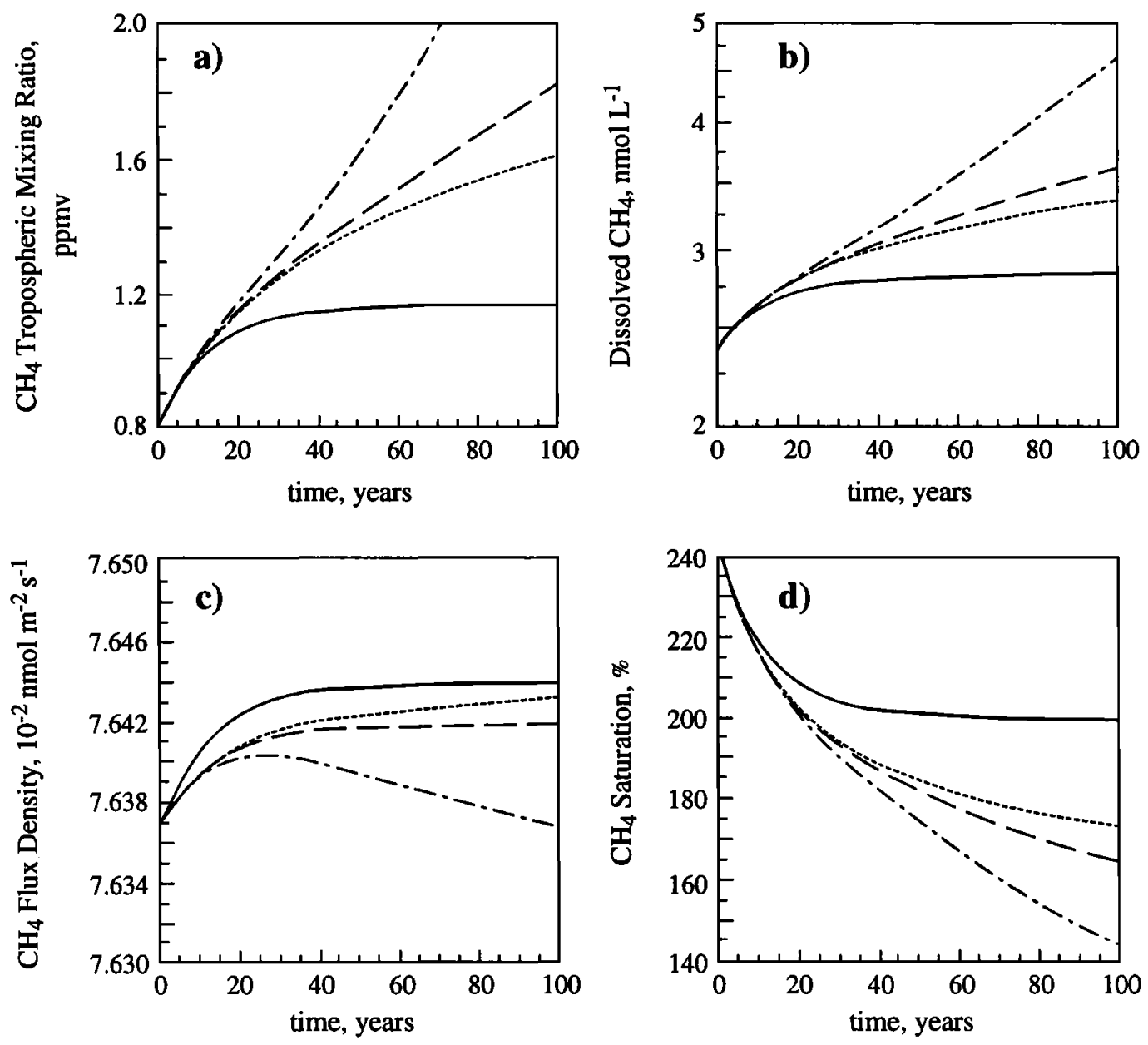

Figure 7. Results of the model calculations with time variation of (a) tropospheric methane, (b) dissolved methane concentration (logarithmic scale), (c) flux densities across the ocean-atmosphere interface, and (d) saturation. Solid line indicates scenario A ( $0 \%$ annual tropospheric growth rate); dashed line, scenario B $(0.7 \%$ annual tropospheric growth rate); dashed-dotted line, scenario $\mathrm{C}$ (accelerated annual tropospheric growth rate); and dotted line, scenario D (decelerated annual tropospheric growth rate).

after approximately 60 years. In scenarios $C$ and $D$ the flux densities show linearly increasing (scenario $C$ ) or linearly decreasing (scenario D) trends after a period of approximately 40 years (Figure 7c). The differences between the flux densities $F$ of the four scenarios are negligible and the resulting oceanic flux $S_{o}$ ( $S_{o}=F \times A$, where $A$ is area of the world's ocean) is in the same range for all scenarios (about $14 \mathrm{Tg} \mathrm{CH}_{4} \mathrm{yr}^{-1}$ ). The analyses of the trend of tropospheric methane during the last decade by Steele et al. [1992] and Dlugokencky et al. [1994] are indicating that scenarios $C$ and $D$ could be regarded as extreme cases which bracket the most realistic case (scenario B). On the basis of the model results we conclude that the world's oceans will continue to be a source of methane even with the observed annual tropospheric growth rates. This is illustrated by Figure $7 \mathrm{~d}$ which shows the resulting trends of the methane saturations. Only with the assumption of an accelerated increase of tropospheric methane is a slight decrease in the flux density across the oceanatmosphere achieved (Figure 7c). Even in this case, however, the ocean remains a source of methane. To generate a negative flux density, an extreme (unrealistic) tropospheric accumulation of methane would be required.
Our prediction of continued oceanic emissions of $\mathrm{CH}_{4}$ is in contrast to the hypothesis of some authors [Cicerone and Oremland, 1988; Lambert and Schmidt, 1993], who suggested a significantly decreasing oceanic flux and postulated that the ocean will become a sink for methane in conjunction with the increase of tropospheric methane mixing ratios. This discrepancy is due to a difference in assumptions. Lambert and Schmidt [1993] assumed that the concentration of dissolved methane is fixed at the present-day value, which would require an increasing internal sink function or decreasing production. Since there is no evidence that these processes are controlled by dissolved methane concentrations, we feel that a constant net production in the surface ocean and thus a constant emission is a more realistic assumption.

\section{Conclusions}

The Baltic Sea and the North Sea are sources of methane to the atmosphere. We observed a strong seasonal variation of the methane saturation in the Baltic Sea. The Oder Bight as a typical shallow coastal region showed higher saturation values due to the 
Oder River plume and sedimentary production than offshore regions of the Baltic Sea. Occasional events, e.g., high wind speeds, could cause a considerable change in the methane saturation in the Oder Bight. On the basis of a compilation of methane measurements from different oceanic regions our reassessment of the global oceanic emissions, applying two different air-sea exchange models, yielded a low limit of 11 $\mathrm{Tg} \mathrm{CH}_{4} \mathrm{yr}^{-1}$ and a high limit of $18 \mathrm{Tg} \mathrm{CH}_{4} \mathrm{yr}^{-1}$. About $75 \%$ of the global oceanic flux was attributed to shelf regions (e.g., Baltic Sea, North Sea, etc.). Model calculations with a simple, coupled three-layer model showed that even with increasing tropospheric concentrations of methane, a net sea-to-air flux of methane to the atmosphere will remain at a level close to the present source strength.

Acknowledgments. We thank the captains and crews of the R/V Alexander von Humboldt and R/P Nordsee for their helpful assistance at sea and G. Schebeske for his technical support. We thank D. J. Erickson (National Center for Atmospheric Research, Boulder, Colorado) for providing the matrices of the transfer coefficients and the sea surface temperatures and $\mathrm{H}$. Gimm for plotting them. We appreciate the support of D. Nehring (Institute for Baltic Sea Research, Warnemünde, Germany) who enabled us to participate on the Baltic Sea expeditions. The campaign on the R/P Nordsee was part of the EUROTRAC subproject ASE. This research was supported by the Max Planck Society.

\section{References}

Bates, T. S., K. C. Kelly, and J. E. Johnson, Concentrations and fluxes of dissolved biogenic gases (DMS, $\mathrm{CH}_{4}, \mathrm{CO}, \mathrm{CO}_{2}$ ) in the Equatorial Pacific during the SAGA 3 experiment, $J$. Geophys. Res., 98, 16,969-16,977, 1993.

Belviso, S., P. Jean-Baptiste, B. C. Nguyen, L. Merlivat, and L. Labeyrie, Deep methane maxima and ${ }^{3} \mathrm{He}$ anomalies across the Pacific entrance to the Celebes Basin, Geochim. Cosmochim. Acta, 51, 2673-2680, 1987.

Berger, U., and J. Heyer, Distribution and activity of methanogenic bacteria in a brackish water ecosystem, Limnologica, 20, 141$144,1990$.

Bianchi, M., D. Marty, J.-L. Teyssie, and S. W. Fowler, Strictly aerobic and anaerobic bacteria associated with sinking particulate matter and zooplankton fecal pellets, Mar. Ecol. Prog. Ser., 88, 55-60, 1992

Brooks, J. M., D. F. Reid, and B. B. Bernard, Methane in the upper water column of the northwestern Gulf of Mexico, $J$. Geophys. Res., 86, 11,029-11,040, 1981.

Bullister, J. L., N. L. Guinasso, and D. R. Schink, Dissolved hydrogen, carbon monoxide, and methane at the CEPEX site, $J$. Geophys. Res., 87, 2022-2034, 1982.

Burke Jr., R. A., D. F. Reid, J. M. Brooks, and D. M. Lavoie, Upper water column methane geochemistry in the eastern tropical North Pacific, Limnol. Oceanogr., 28, 19-32, 1983.

Butler, J. H., R. D. Jones, J. H. Garber, and L. I. Gordon, Seasonal distribution and turnover of reduced trace gases and hydroxylamine in Yaquina Bay, Oregon, Geochim. Cosmochim. Acta, 5l, 697-706, 1987.

Butler, J. H., J. H. Elkins, C. M. Brunson, K. B. Egan, T. M. Thompson, T. J. Conway, and B. D. Hall, Trace gases in and over the West Pacific and East Indian Oceans during the El NiñoSouthern Oscillation event of 1987, Data Rep. ERL ARL-16, Air Resour. Lab., Natl. Oceanic and Atmos. Admin., Silver Spring, Md., 1988.

Charlou, J. L., L. Dmitriev, H. Bougault, and H. D. Needham, Hydrothermal $\mathrm{CH}_{4}$ between $12^{\circ} \mathrm{N}$ and $15^{\circ} \mathrm{N}$ over the Mid-Atlantic Ridge, Deep-Sea Res., Part A, 35, 121-131, 1988.

Charlou, J. L., H. Bougault, P. Appriou, P. Jean-Baptiste, J.
Etoubleau, and A. Birolleau, Water column anomalies associated with hydrothermal activity between $11^{\circ} 40^{\prime}$ and $13^{\circ} \mathrm{N}$ on the East Pacific Rise: Discrepancies between tracers, Deep-Sea Res., Part A, 38, 569-596, 1991.

Cicerone, R. J., and R. S. Oremland, Biogeochemical aspects of atmospheric methane, Global Biogeochem. Cycles, 2, 299-327, 1988.

Conrad, R., and W. Seiler, Methane and hydrogen in seawater (Atlantic Ocean), Deep-Sea Res., Part A, 35, 1903-1917, 1988.

Crutzen, P. J., Methane's sinks and sources, Nature, 350, 380-381, 1991.

Cynar, F. J., and A. A. Yayanos, The distribution of methane in the upper waters of the Southern California Bight, J. Geophys. Res, 97, 11,269-11,285, 1992.

de Angelis, M. A., and M. D. Lilley, Methane in the surface waters of Oregon estuaries and rivers, Limnol. Oceanogr., 32, 716-722, 1987.

de Angelis, M. A., and M. I. Scranton, Fate of methane in the Hudson River and Estuary, Global Biogeochem. Cycles, 7, 509523, 1993.

Dlugokencky, E. J., K. A. Masaire, P. M. Lang, P. P. Tans, L. P. Steele, and E. G. Nisbet, A dramatic decrease in the growth rate of atmospheric methane in the northern hemisphere during 1992, Geophys. Res. Lett., 21, 45-48, 1994.

Ehhalt, D. H., The atmospheric cycle of methane, Tellus, 26, 58-70, 1974.

Ehhalt, D. H., and U. Schmidt, Sources and sinks of atmospheric methane, Pure Appl. Geophys., 116, 452-464, 1978.

Ehlin, U., Hydrology of the Baltic Sea, in The Baltic Sea, edited by A. Voipio, pp. 123-134, Elsevier Science, New York, 1981.

Erickson III, D. J., Simulation of the global air-sea transfer velocity of helium, Geophys. Res. Lett., 15, 1495-1498, 1988.

Erickson III, D. J., A stability dependent theory for air-sea gas exchange, J. Geophys. Res., 98, 8471-8488, 1993.

Gamo, T., J.-I. Ishibashi, H. Sakai, and B. Tilbrook, Methane anomalies in seawater above the Loihi submarine summit area, Hawaii, Geochim. Cosmochim. Acta, 51, 2857-2864, 1987.

Gamo, T., J.-I. Ishibashi, K. Shitshima, M. Kinoshita, M. Watanabe, E. Nakayama, Y. Sohrin, E.-S. Kim, T. Masuzawa, and K. Fujioka, Anomalies of bottom $\mathrm{CH}_{4}$ and trace metal concentrations associated with high heat flow at the Calyptogena community off Hatsu-shima Island, Sagami Bay, Japan: A preliminary report of Tansei Maru KT-88-1 cruise Leg-1, Geochem. J., 22, 215-230, 1988.

Garratt, J. R., Review of drag coefficients over oceans and continents, Mon. Weather Rev., 105, 915-929, 1977.

Heyer, J., U. Berger, and R. Suckow, Methanogenesis in different parts of a brackish water ecosystem, Limnologica, 20, 135-139, 1990.

Houghton, J. T., G. J. Jenkins, and J. J. Ephraums (Eds.), Climate Change: The IPCC Scientific Assessment, 365 pp., Cambridge University Press, New York, 1990.

Hovland, M., A. G. Judd, and R. A. Burke Jr., The global flux of methane from shallow submarine sediments, Chemosphere, 26, 559-578, 1993.

Jähne, B., G. Heinz, and W. Dietrich, Measurements of the diffusion coefficients of sparingly soluble gases in water, J. Geophys. Res., $92,10,767-10,776,1987$.

Jean-Baptiste, P., S. Belviso, G. Alaux, B. C. Nguyen, and N. Mihalopoulos, ${ }^{3} \mathrm{He}$ and methane in the Gulf of Aden, Geochim. Cosmochim. Acta, 54, 111-116, 1990.

Jones, R. D., Carbon monoxide and methane distribution and consumption in the photic zone of the Sargasso Sea, Deep-Sea Res., Part A, 38, 625-635, 1991.

Jones, R. D., and J. A. Amador, Methane and carbon monoxide production, oxidation, and turnover times in the Caribbean Sea as influenced by the Orinoco River, J. Geophys. Res., 98, 23532359, 1993.

Karl, D. M., and B. D., Tilbrook, Production and transport of 
methane in oceanic particulate organic matter, Nature, 368, 732734, 1994.

Khalil, M. A. K., and R. A. Rasmussen, Sources, sinks, and seasonal cycles of atmospheric methane, J. Geophys. Res., 88, 5131-5144, 1983.

Khalil, M. A. K., and R. A. Rasmussen, Atmospheric methane: Recent global trends, Environ. Sci. Technol., 24, 549-553, 1990.

Kullenberg, G., Physical oceanography, in The Baltic Sea, edited by A. Voipio, pp. 135-182, Elsevier Science, New York, 1981.

Lambert, G., and S. Schmidt, Reevaluation of the oceanic flux of methane: uncertainties and long term variation, Chemosphere, 26, 579-589, 1993.

Lammers, S., Methane in the water column off Sakhalin, paper presented at First Workshop on the Russian-German Cooperation in the Sea of Okhotsk-Kuril Island Arc System, sponsored by P. P. Shirshov Institute of Oceanology, Moscow, 1993.

Lammers, S., and E. Suess, An improved head-space analysis method for methane in seawater, Mar. Chem., 47, 115-125, 1994.

Lamontagne, R. A., J. W. Swinnerton, V. J. Linnebom, and W. D. Smith, Methane concentrations in various marine environments, J. Geophys. Res., 78, 5317-5325, 1973.

Lamontagne, R. A., J. W. Swinnerton, and V. J. Linnenbom, $\mathrm{C}_{1}-\mathrm{C}_{4}$ hydrocarbons in the North and South Pacific, Tellus, 26, 71-77, 1974.

Lavoie, D. M., D. F. Reid, I. P. DePalma, and J. D. Hayes, Chemical, biological, and physical measurements from the Mediterranean Sea, summer 1980, Tech. Note 138, Naval Ocean Res. and Dev. Activity, NSTL Station, Miss., 1982.

Li, Y.-H., T.-H. Peng, W. S. Broecker, and H. G. Östlund, The average vertical mixing coefficient for the oceanic thermocline, Tellus, Ser. B., 36B, 212-217, 1984.

Lilley, M. D., J. A. Baross, and L. I. Gordon, Dissolved hydrogen and methane in Saanich Inlet, British Columbia, Deep-Sea Res., Part A, 29, 1471-1484, 1982.

Liss, P. S., and L. Merlivat, Air-sea exchange rates: Introduction and synthesis, in The Role of Air-Sea Exchange in Geochemical Cycling, edited by P. Buat-Ménard, pp. 113-127, D. Reidel, New York, 1986.

Macdonald, R. W., Distribution of low-weight hydrocarbons in the southern Beaufort Sea, Environ. Sci. Technol., 10, 1241-1246, 1976.

Menard, H. W., and S. M. Smith, Hypsometry of the ocean basin provinces, J. Geophys. Res., 71, 4305-4325, 1966.

Omstedt, A., Modelling the Baltic Sea as thirteen sub-basins with vertical resolution, Tellus, Ser. A, 42A, 286-301, 1990.

Otto, L., J. T. F. Zimmermann, G. K. F. Furnes, M. Mork, R. Saetre, and G. Becker, Review of the physical oceanography of the North Sea, Neth. J. Sea Res., 26, 161-238, 1990.

Owens, N. J. P., C. S. Law, R. F. C. Mantoura, P. H. Burkill, and C. A. Llewellyn, Methane flux to the atmosphere from the Arabian Sea, Nature, 354, 293-296, 1991.

Prinn, R., et al., Global average concentration and trend for hydroxyl radicals deduced from ALE/GAGE trichloroethane (methyl chloroform) data for 1978-1990, J. Geophys. Res., 97, 2445-2461, 1992.

Rasmussen, R. A., and M. A. K. Khalil, Atmospheric methane in the recent and ancient atmospheres: Concentrations, trends, and interhemispheric gradient, J. Geophys. Res., 89, 11,599-11,605, 1984.

Reeburgh, W. S., B. B. Ward, S. C. Whalen, K. A. Sandbeck, K. A. Kilpatrick, and L. J. Kerkhof, Black Sea methane geochemistry, Deep-Sea Res., Part A, 38, S1189-1210, 1991.

Scranton, M. I., and P. G. Brewer, Occurrence of methane in the near-surface waters of the western subtropical North-Atlantic, Deep-Sea Res., 24, 127-138, 1977.

Scranton, M. I., and J. W. Farrington, Methane production in the waters of Walvis Bay, J. Geophys. Res., 82, 4947-4952, 1977.

Scranton, M. I., and K. McShane, Methane fluxes in the southern North Sea: The role of European rivers, Cont. Shelf Res., 11, 37 $52,1991$.

Scranton, M. I., P. Crill, M. de Angelis, P. L. Donaghay, and J. M. Sieburth, The importance of episodic events in contolling the flux of methane from an anoxic basin, Global Biogeochem. Cycles, 7, 491-507, 1993.

Siedler G., and H. Peters, Properties of seawater, in Oceanography, Landolt-Börnstein, New Ser., Group V, vol. 3a, edited by J. Sündermann, pp. 233-264, Springer-Verlag, New York, 1986.

Steele, L. P., P. J. Fraser, R. A. Rasmussen, M. A. K. Khalil, T. J. Conway, A. J. Crawford, R. H. Gammon, K. A. Masarie, and K. W. Thoning, The global distribution of methane in the troposphere, J. Atmos. Chem., 5, 125-171, 1987.

Steele, L. P., E. J. Dlugokencky, P. M. Lang, P. P. Tans, R. C. Martin, and K. A. Masarie, Slowing down of the global accumulation of atmospheric methane during the 1980s, Nature, 358, 313-316, 1992.

Swinnerton, J. W., V. J. Linnenbom, and C. H. Cheek, Distribution of methane and carbon monoxide between the atmosphere and natural waters, Environ. Sci. Technol., 9, 836-838, 1969.

Traganza, E. D., J. W. Swinnerton, and C. H. Cheek, Methane supersaturation and ATP-zooplankton blooms in near-surface waters of the Western Mediterranean and the subtropical North Atlantic Ocean, Deep-Sea Res., Part A, 26, 1237-1245, 1979.

Vaghjiani, G. L., and A. R. Ravishankara, New measurement of the rate coefficient for the reaction of $\mathrm{OH}$ with methane, Nature, 350, 406-409, 1991.

Wanninkhof, R., W. Asher, R. Weppering, H. Chen, P. Schlosser, C. Langdon, and R. Sambrotto, Gas transfer experiments on Georges Bank using two volatile deliberate tracers, J. Geophys. Res., 98, 20,237-20,248, 1993.

Ward, B. B., The subsurface methane maximum in the Southern California Bight, Cont. Shelf Res., 12, 735-752, 1992.

Ward, B. B., K. A. Kilpatrick, P. C. Novelli, and M. I. Scranton, Methane oxidation and methane fluxes in the ocean surface layer and deep anoxic waters, Nature, 327, 226-229, 1987.

Ward, B. B., K. A. Kilpatrick, A. E. Wopat, E. C. Minnich, and M. E. Lidstrom, Methane oxidation in Saanich Inlet during summer stratification, Cont. Shelf Res., 9, 65-75, 1989.

Wiesenburg, D. A., and N. L. Guinasso Jr., Equilibrium solubilities of methane, carbon monoxide, hydrogen in water and seawater, J. Chem. Eng. Data, 24, 356-360, 1979.

Williams, R. T., and A. E. Bainbridge, Dissolved $\mathrm{CO}, \mathrm{CH}_{4}$, and $\mathrm{H}_{2}$ in the Southern Ocean, J. Geophys. Res., 78, 2691-2694, 1973.

Wilson, D. F., J. W. Swinnerton, and R. A. Lamontagne, Production of carbon monoxide and gaseous hydrocarbons in seawater: Relation to dissolved organic carbon, Science, 168, 1577-1579, 1970.

Woodwell, G. M., Aquatic systems as part of the biosphere, in Fundamentals of Aquatic Ecosystems, edited by R. S. K. Barnes and K. H. Mann, Blackwell Scientific, Boston, Mass., 1980.

M. O. Andreae, H. W. Bange, U. H. Bartell, S. Rapsomanikis, Biogeochemistry Department, Max Planck Institute for Chemistry, P. O. Box 3060, D-55020 Mainz, Germany.

(Received September 9, 1993; revised August 15, 1994; accepted August 19, 1994.) 